Review

\title{
Environmentally Concerned Logistics Operations in Fuzzy Environment: A Literature Survey
}

\author{
Ozden Tozanli ${ }^{1, *}$, Gazi Murat Duman ${ }^{1}$, Elif Kongar ${ }^{2}$ and Surendra M. Gupta ${ }^{3}$ \\ 1 Department of Technology Management, School of Engineering, University of Bridgeport, Bridgeport, \\ CT 06604, USA; gduman@my.bridgeport.edu \\ 2 Departments of Mechanical Engineering and Technology Management, School of Engineering, \\ University of Bridgeport, Bridgeport, CT 06604, USA; kongar@bridgeport.edu \\ 3 Department of Mechanical and Industrial Engineering, Northeastern University, Boston, MA 02115, USA; \\ s.gupta@northeastern.edu \\ * Correspondence: otozanli@my.bridgeport.edu; Tel.: +1-203-576-4379
}

Academic Editor: John D. Kasarda

Received: 18 April 2017; Accepted: 8 June 2017; Published: 13 June 2017

\begin{abstract}
Growing environmental awareness coupled with stricter governmental regulations has fueled the need for integrating sustainability into supply chain and logistics activities. Accordingly, recent studies in the literature have emphasized the significance of environmentally concerned logistics operations (ECLO). Research in the broad area of ECLO encompasses a wide range of topics including sustainable supply chain, green supply chain, closed-loop supply chain, low-carbon logistics, and waste management. In this paper, a comprehensive content analysis and area review is presented. Over 800 papers published between 1994 and 2017 in peer-reviewed journals, proceedings, and book chapters are utilized. These papers are analyzed in consecutive stages after being reviewed under a structural dimension process that addresses the fields of environmentally concerned logistics operations. Following the state-of-the-art review, a detailed analysis of ECLO research with a special emphasis on fuzzy applications is provided. The findings clearly indicate that the fuzzy multi-criteria decision making technique is a frequently used hybrid method, whereas fuzzy sets theory and other fuzzy hybrid techniques identify a gap in the related literature. This paper provides further critical analysis and other research suggestions in order to clarify these gaps and offer additional research perspectives. This information may provide extensive data that will enable future researchers to fill these gaps within this field.
\end{abstract}

Keywords: environmentally concerned logistics; fuzzy sets; multi-criteria decision making; content analysis; sustainability

\section{Introduction}

Recently, environmentally concerned logistics operations (ECLO) have received attention from both industry and academia for their ability to reduce environmental pollution caused by an increase in global transportation activities. Growing environmental awareness and strict regulations are two major factors that influence how producers and consumers carry out environmentally responsible production and product disposal operations [1]. As a result, several organizations restructured their business operations to be environmentally and ethically accountable [2]. Researchers have investigated the impact of these supply chain (SC) operations from a sustainability perspective.

Supply chain management (SCM) involves entire business operations such as planning, sourcing, production, and distribution. SCM includes all parties from the original suppliers to the end users. The concept, however, does not specifically address any one of these processes [3,4]. On the other hand, sustainability embedded SCM considers factors beyond the supply chain network by including 
product design, manufacturing by-products, by-products produced during product use, product life extension, product end-of-life, and recovery processes at end-of-life [5]. As opposed to traditional or forward SCM, which focuses on the economic aspects of a logistics network, sustainable supply chain management (SSCM) embodies several supply chain operations and unites the traditional supply chain management while ensuring environmentally friendly practices [6]. Embedding sustainability into SCM also ensures corporations to maintain competitiveness in consideration of environmental and social issues while implementing economic sustainability [7]. Therefore, SSCM becomes a prominent area of research wherein the entire process is examined by the triple bottom line (TBL) that encompasses the environmental, social and economic aspects [8].

Environmentally concerned SCM is divided into categories such as: sustainable SCM (SSCM), green SCM (GSCM), low-carbon logistics, waste management and closed-loop SCM (CLSCM). Since the majority of GSCM, parts of CLSCM, waste management, and low-carbon logistics topics fulfill the environmental sustainability criteria, these categories are included within the SSCM concept [7,9-11]. In this regard, a SSCM framework is constructed as depicted in Figure 1. Additionally, GSCM and CLSCM target many environmental and economic sustainability dimensions, while low-carbon logistics focuses on higher environmental performance. GSCM has a total of 12 definitions in the literature [11], and is also named green logistics, environmental logistics, environmental SCM, and supply chain environmental management [12-14]. Regardless, the topic is mainly examined in six categories such as green manufacturing and packaging, green logistics, green marketing, green suppliers, green stock, and green eco-design [2,15]. Furthermore, environmental management systems and life cycle analysis are studied by GSCM [16]. CLSCM, on the other hand, is examined as reverse logistics, recycling, remanufacturing and reuse, and product recovery [3,17]. Product recovery includes the collection, inspection, disassembly, reuse, remanufacturing, and recycling operations with a focus on retrieving the value added to EOL products $[17,18]$. While low-carbon logistics have been studied under different topics such as greenhouse gas (GHG) emissions, carbon footprint, carbon emission, and $\mathrm{CO}_{2}$ emissions; waste management is often included in hazardous substance management and solid waste management research. Sbihi and Eglese [19] considered waste management to be a part of green logistics since the transportation of waste materials involves environmental movements.

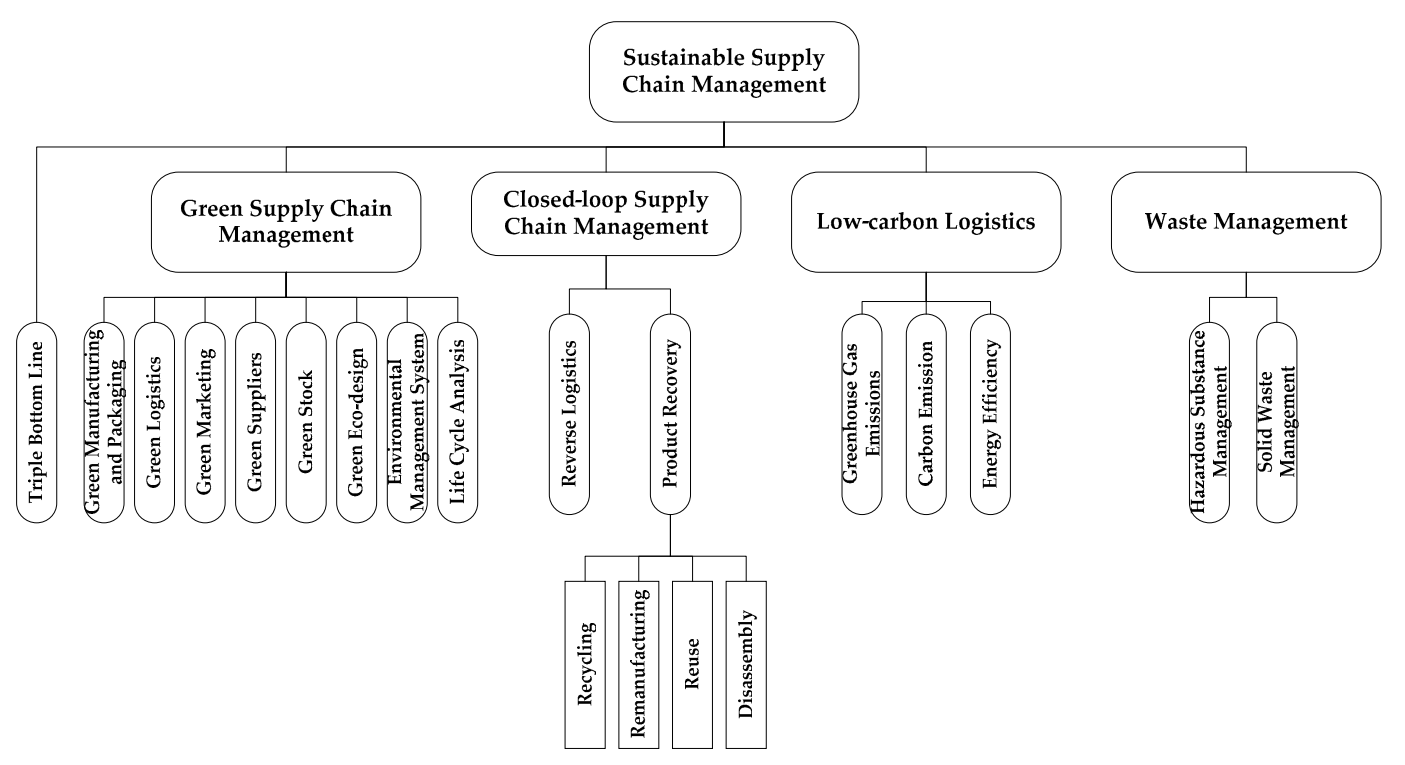

Figure 1. Sustainable Supply Chain Management (SSCM) framework.

Unlike the existing reviews, this paper gathers SSCM, GSCM, reverse logistics in CLSCM, low-carbon logistics, and waste management under the umbrella of Environmentally Concerned Logistics Operations (ECLO). The studies within the fields of ECLO offer a variety of qualitative 
and quantitative research approaches such as conceptual theory, case study, empirical analysis, and quantitative modeling. Conceptual theory studies focus on the concepts and introduce new methods; whereas, case studies provide real-life examples of these methods. Empirical analysis represents the statistical analyses conducted to test these methods. The quantitative modeling represents mathematical programming and solution approaches such as mathematical modeling, simulation, heuristics, hybrid and analytical models [2,3,7]. The need for quantitative models in environmentally conscious studies resulted in various deterministic, probabilistic, heuristics algorithms, and various software focused on economically viable design, manufacturing, logistics, recycling, disassembly and remanufacturing operations [1]. Although there are some review papers that provide a content analysis on quantitative modeling approaches within the fields of ECLO, no study exists that focuses on a systematic literature review on the fuzzy environmentally concerned logistics models. With this motivation, this survey paper provides a detailed review of quantitative models in fuzzy environment, by conducting a content analysis including 804 papers that appeared from 1994 to 2017 in English-written peer-reviewed journals and proceedings.

The rest of the paper is organized as follows. A detailed description of the background research is presented in Section 2. Section 3 describes the methodology implemented for the paper selection for each step of the content analysis. Results and findings of the content analysis are detailed in Section 4. Summary and discussions are provided in Section 5. Finally, Section 6 presents concluding remarks and information regarding future research.

\section{Background}

Several literature on environmentally concerned surveys have been published. For instance, Srivastava [20] studied GSCM related research and focused on reverse logistics using several significant keywords such as remanufacturing, green supply chain, green purchasing, and waste management. Additionally, Sarkis et al. [21] reviewed the literature on GSCM under nine organizational theories of complexity, ecological modernization, information, institutional, resource-based view, resource dependence, social network, stakeholder, and transaction and economics. Moreover, Igarashi et al. [22] presented a literature review on green supplier selection and developed a conceptual model. Similarly, Govindan et al. [23] offered a literature review about green supplier selection and the evaluation of the multi-criteria decision making approaches.

Another literature review on SSCM was conducted by Seuring and Müller [10]. They provided a conceptual framework and implemented a quantitative content analysis using the keywords of sustainability, sustainable development, environmental, green, ecological, and social and ethical. Furthermore, Gold et al. [24] examined the literature to present a quantitative content analysis of case study publications by taking sustainability, green supply, corporate environmental responsibility and strategic purchasing into account, and then proposed a conceptual framework of SSCM. In addition, Ilgin and Gupta [1] conducted a systematic literature review in the field of environmentally conscious manufacturing and product recovery (ECMPRO) and investigated environmentally conscious product design, reverse logistics, closed-loop supply chains, remanufacturing, and disassembly; while Ilgin et al. [17] further studied the literature on ECMPRO addressing the use of multi-criteria decision making (MCDM) techniques. Hassini et al. [25] analyzed the literature on SSCM and the performance measures and highlighted the reliable performance measures. Also, Gao et al. [26] studied a content analysis on sustainable supply chain innovation where they identified a conceptual framework including the characteristics of this field.

Despite the fact that a considerable number of systematic literature surveys have been published, the content analyses that focus on quantitative modeling approaches in the sustainability field are limited. Seuring [27] reviewed the modeling approaches for forward SSCM and concluded that the dominant modeling approaches consist of equilibrium models, multi-criteria decision making (MCDM) and analytic hierarchy process (AHP). Brandenburg et al. [3] also investigated the SSCM related quantitative models. Additionally, Brandenburg and Rebs [7] presented a content analysis of 
model based SSCM by aiming at categorizing modeling approaches according to their model types and model purposes. Existing studies, however, do not provide a comprehensive content analysis of the fuzzy environmentally concerned logistics methodologies. With this motivation, this survey paper provides a detailed review of quantitative models in fuzzy environment. Unlike existing studies, the fields of SSCM, GSCM, CLSCM, reverse logistics, low-carbon logistics, and waste management have been grouped under Environmentally Concerned Logistics Operations (ECLO). In spite of the increasing number of papers, sustainability integrated supply chain management is still an emerging field in literature. With this motivation, this research aims at identifying and prioritizing research gaps while discussing future research needs in related areas.

\section{Methodology}

Systematic literature reviews are structured comprehensive reviews that include a high level of transparency and consistency of information [24,28-31]. There are a large variety of literature survey approaches provided in the literature. Out of these, narrative synthesis, meta-ethnography, and realist synthesis have been reported to increase rapidly across different disciplines [32]. Content analysis, a widely used qualitative research technique [33], is known to be effective when a systematic descriptive review is required to accurately describe and determine the main contributing researchers and journals [34]. With this motivation, this research presents a quantitative content analysis to analyze the growth in the ECLO related literature. The findings of the review are then further detailed to highlight the least developed areas of fuzzy based research in related fields providing guidelines for future studies. As with all comprehensive and consistent literature reviews, the survey followed the guidelines for reporting search strategies including the range of years, the purposive sampling strategy along with the inclusion and exclusions, language restrictions, the terms used and the electronic sources. Aiming at developing a reliable knowledge base by accumulating knowledge from a range of studies, explicit descriptions of the types of studies included in the systematic review are clearly outlined to limit selection bias [29]. The review included several ECLO categories, viz., SSCM, GSCM, CLSCM, reverse logistics, low-carbon logistics, and waste management, where sustainability in SCM is emphasized in order to answer the following research questions:

- Which dimensions of sustainability are mostly employed in the literature?

- Which methods and approaches are preferred in fuzzy ECLO models?

- Which future work suggestions should be examined?

To answer these questions, a content analysis was applied to categorize and evaluate the related literature. To this point, the process of content analysis consists of four iterative steps $[35,36]$. These steps are defined as follows [3,35]:

1. Material collection: The material to be collected and the unit of analysis are defined and delimited.

2. Descriptive analysis: Formal aspects of the material are assessed.

3. Category selection: Structural dimensions including the major topics of analysis and related analytic categories with detailed classifications of each structural dimension are selected to be applied to the collected material.

4. Material evaluation: The content of the papers is analyzed according to the structural dimensions and analytic categories to identify relevant issues and to interpret the results.

\subsection{Content Analysis}

\subsubsection{Material Collection}

In this literature review, the unit of analysis is defined as research articles published in English-written peer-reviewed journals, proceedings, and book chapters. A keyword-based search via online databases is an easier and effective way to conduct a broad content check on a specific topic [3,7,37]. By replicating the content analyses of Seuring and Müller [10] and Brandenburg et al. [3], 
a structured keyword search was implemented in major databases and publishers such as Elsevier, Emerald, IEEE Xplore, ProQuest ABI-Inform, Wiley, Springer, Taylor and Francis, Hindawi, and Inderscience. The steps of the structured keyword is depicted in Figure 2. The first stage was a broader search where a general keyword search for pairs of terms such as ("Sustainability" OR "Sustainable") AND ("Supply Chain" OR “Logistics"), ("Green" OR “Environmental”) AND ("Supply Chain" OR “Logistics"), (“Closed-Loop" OR “Low-Carbon") AND ("Supply Chain" OR “Logistics") was performed $[3,25]$. In the second stage, the search was focused on quantitative models, and then particular methods such as Fuzzy, Grey Sets, Rough set, Multi-criteria decision making (MDCM) and Game theory were further added into the keywords. In the final stage, the papers which do not meet all four criteria, given below, were excluded from the overall pool of papers:

- Papers must be written in the English language in peer-reviewed scientific journals, conference proceedings, or book chapters that cover the 24 year-period from 1994 to 2017.

- Publications that do not address environmental criteria of sustainability, and focus on economic, ethical behaviors, or political science are excluded from the analysis.

- The paper contains formal and quantitative model-based publications in the field of ECLO. Conceptual frameworks and empirical analyses that use statistical approaches are not considered.

- Publications which do not focus on supply chain or logistics as the main topic are excluded from the analysis.

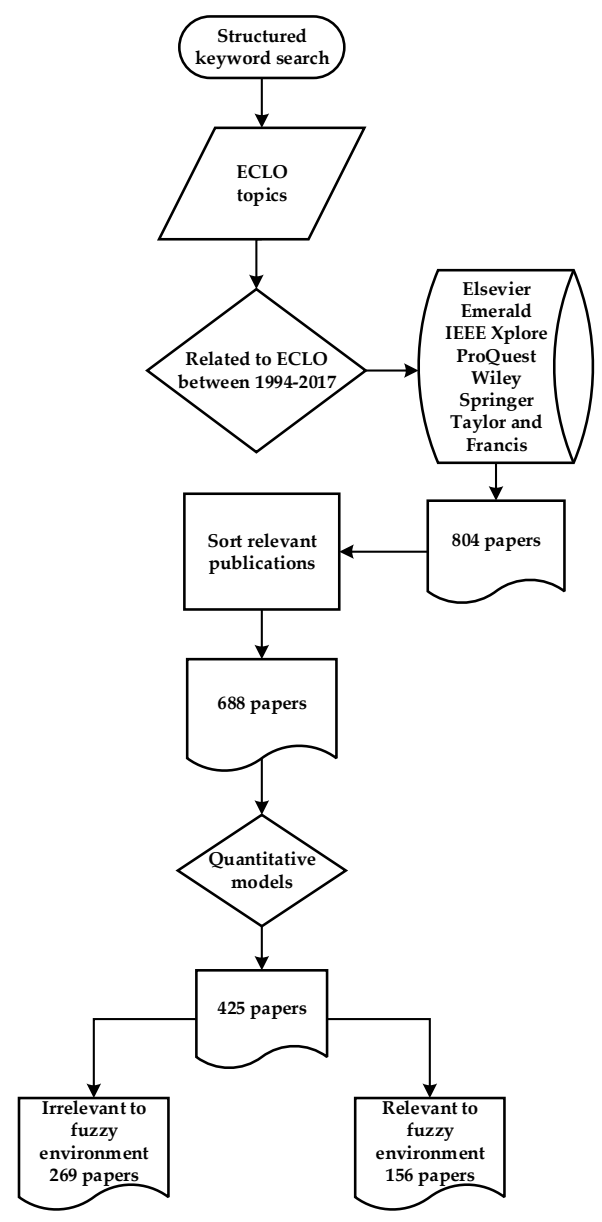

Figure 2. Material collection flowchart.

After the initial search, 804 publications that appeared from 1994 to 2017 were collected. Figure 3 presents the number of publications categorized according to the sustainability dimensions. As it can be 
observed from the figure, there are 724, 707, and 292 publications that address the economic dimension, the environmental dimension, and the social dimension, respectively. In these papers, environmental criteria are also interchangeably used with environmental performance or environmental sustainability by various authors. The papers that cover the three dimensions of sustainability, namely triple bottom line, constitutes 347 of 804 papers, whereas only 98 out of the total sample use the term of "Triple Bottom Line". In this paper, the articles that did not consider environmental criteria were excluded from the analysis even though they contain the keyword "sustainability". Those papers focused on either economic sustainability or social sustainability.

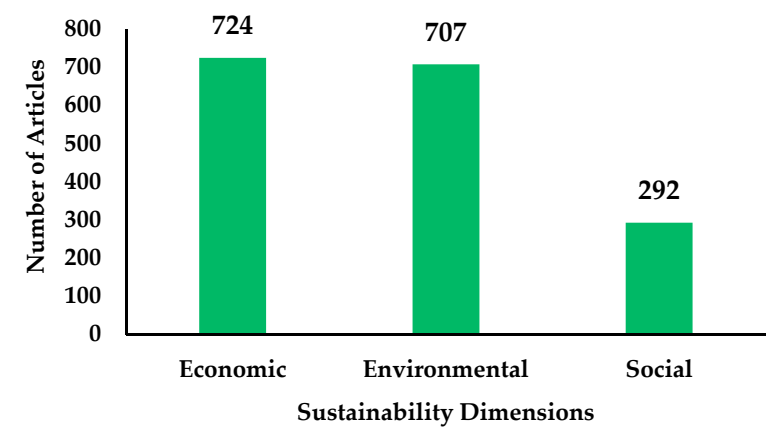

Figure 3. Assignments of publications to the sustainability dimensions.

The remaining 707 papers were analyzed for their quantitative models. In this step, the papers that studied conceptual framework, literature review, case studies and empirical researches applying statistical approaches were excluded. Therefore, 425 of the publications containing formal quantitative models were extracted from the sample. Out of these 425 publications, 268 of them embodied fuzzy, grey sets, rough set, MCDM and game theory. Finally, 156 articles out of the total 804 papers that matched $19 \%$ of the total number of papers comprised fuzzy environmentally concerned logistics methodologies. These papers met all four of the required criteria, and were selected for review and evaluation in detail.

\subsubsection{Descriptive Analysis}

The formal assessment of the analysis includes annual data for the total number of publications over time. The top ten cited articles are also provided along with the distribution of papers in leading journals for the same time frame. The publications were sorted based on this assessment. The body of literature on ECLO contains 707 papers extracted from 246 journals, 31 proceedings, and 4 books from 1994 to 2017 as shown in Figure 4. The figure indicates the number of publications have shown substantial growth over the last 13 years. Conversely, publications hardly increased during 1994 through 2004. One plausible explanation for this trend is growing sustainable practices fostered by increasing environmental awareness.

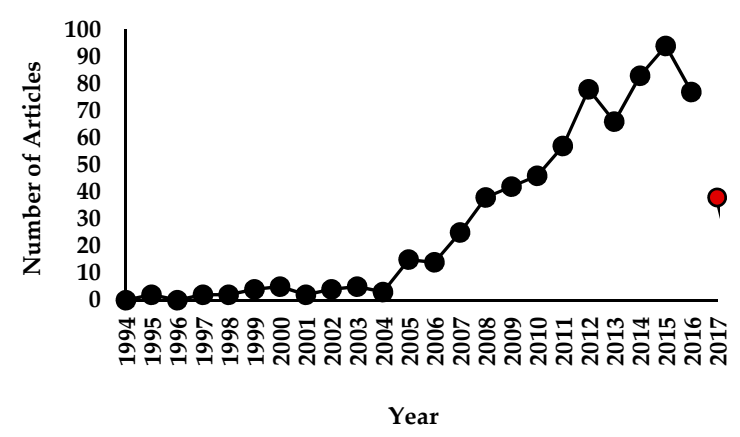

Figure 4. Yearly distribution of the publications over time. 
Table 1 illustrates the frequency distribution of papers in primary ECLO journals, viz. Journal of Cleaner Production (JCLP), International Journal of Production Economics (IJPE), European Journal of Operational Research (EJOR), Resources, Conservation and Recycling (RCR), the Computers and Industrial Engineering (C\&IE), Expert Systems with Applications (ESWA), Omega, International Journal of Production Research (IJPR), Transportation Research Part E: Logistics and Transportation Review (TRE), and Supply Chain Management: An International Journal (SCM:IJ). The distribution of papers in other journals is shown in Table A1 in Appendix A based on the table exhibited by Agrawal et al. [38].

Table 1. Frequency distribution of articles according to main journals.

\begin{tabular}{|c|c|c|c|c|c|c|c|c|c|c|c|}
\hline $\begin{array}{c}\text { Journal } \\
\text { Year }\end{array}$ & JCLP & IJPE & EJOR & RCR & C\&IE & Omega & ESWA & IJPR & TRE & SCM:IJ & Others \\
\hline 2017 & 18 & 2 & 0 & 1 & 4 & 4 & 1 & 0 & 0 & 0 & 8 \\
\hline 2016 & 23 & 6 & 3 & 4 & 6 & 3 & 0 & 2 & 1 & 0 & 29 \\
\hline 2015 & 15 & 16 & 1 & 4 & 2 & 3 & 2 & 1 & 1 & 0 & 49 \\
\hline 2014 & 5 & 9 & 8 & 2 & 2 & 5 & 3 & 3 & 2 & 0 & 44 \\
\hline 2013 & 20 & 3 & 2 & 3 & 2 & 0 & 1 & 2 & 1 & 0 & 32 \\
\hline 2012 & 0 & 15 & 3 & 1 & 1 & 1 & 6 & 2 & 1 & 5 & 43 \\
\hline 2011 & 3 & 5 & 0 & 7 & 1 & 1 & 4 & 0 & 3 & 0 & 33 \\
\hline 2010 & 2 & 5 & 2 & 0 & 1 & 0 & 0 & 1 & 0 & 1 & 36 \\
\hline 2009 & 2 & 0 & 2 & 3 & 2 & 0 & 1 & 2 & 2 & 2 & 26 \\
\hline 2008 & 5 & 5 & 0 & 0 & 1 & 3 & 1 & 0 & 3 & 3 & 19 \\
\hline 2007 & 2 & 2 & 2 & 0 & 0 & 0 & 0 & 3 & 0 & 1 & 15 \\
\hline 2006 & 2 & 1 & 1 & 1 & 0 & 1 & 0 & 1 & 0 & 0 & 7 \\
\hline 2005 & 2 & 0 & 0 & 0 & 1 & 0 & 0 & 0 & 1 & 2 & 10 \\
\hline 2004 & 1 & 1 & 0 & 0 & 0 & 0 & 0 & 0 & 0 & 0 & 1 \\
\hline 2003 & 1 & 0 & 1 & 0 & 0 & 0 & 1 & 1 & 0 & 0 & 1 \\
\hline 2002 & 0 & 0 & 1 & 0 & 0 & 1 & 0 & 0 & 1 & 0 & 1 \\
\hline 2001 & 0 & 0 & 0 & 0 & 0 & 0 & 0 & 0 & 0 & 0 & 2 \\
\hline 2000 & 0 & 0 & 1 & 0 & 0 & 1 & 0 & 0 & 0 & 0 & 3 \\
\hline 1999 & 0 & 0 & 0 & 0 & 2 & 0 & 0 & 0 & 0 & 0 & 2 \\
\hline 1998 & 0 & 0 & 0 & 0 & 0 & 0 & 0 & 0 & 0 & 0 & 2 \\
\hline 1997 & 0 & 0 & 1 & 0 & 0 & 0 & 0 & 0 & 0 & 0 & 1 \\
\hline 1996 & 0 & 0 & 0 & 0 & 0 & 0 & 0 & 0 & 0 & 0 & 0 \\
\hline 1995 & 0 & 0 & 1 & 0 & 0 & 0 & 0 & 0 & 0 & 0 & 1 \\
\hline 1994 & 0 & 0 & 0 & 0 & 0 & 0 & 0 & 0 & 0 & 0 & 0 \\
\hline Total & 101 & 70 & 29 & 26 & 25 & 23 & 20 & 18 & 16 & 14 & 365 \\
\hline
\end{tabular}

Table 2 presents Google Scholar search engine's top ten most cited SCM publications. From the citation analysis in Table 2, it is concluded that literature reviews and conceptual manuscripts constituted the majority of frequently cited articles. The popular SCM publications mostly focused on green-oriented models; whereas, reverse logistics studies were frequently cited.

Table 2. Top ten most cited articles in the literature data as of 29 May 2017.

\begin{tabular}{|c|c|c|c|c|}
\hline Authors & Title & Year & Journal & Citation \\
\hline $\begin{array}{l}\text { Fleischmann, Moritz; } \\
\text { Bloemhof-Ruwaard, Jacqueline M.; } \\
\text { Dekker, Rommert; van der Laan, } \\
\text { Erwin; van Nunen, Jo A.E.E.; van } \\
\text { Wassenhove, Luk N. }\end{array}$ & $\begin{array}{l}\text { Quantitative models for reverse } \\
\text { logistics: A review }\end{array}$ & 1997 & $\begin{array}{l}\text { European Journal of } \\
\text { Operations Research }\end{array}$ & 2492 \\
\hline Seuring, Stefan; Müller, Martin & $\begin{array}{l}\text { From a literature review to } \\
\text { a conceptual framework for } \\
\text { sustainable supply chain } \\
\text { management }\end{array}$ & 2008 & $\begin{array}{l}\text { Journal of Cleaner } \\
\text { Production }\end{array}$ & 2468 \\
\hline Srivastava, Samir K. & $\begin{array}{l}\text { Green supply-chain } \\
\text { management: A state-of-the-art } \\
\text { literature review }\end{array}$ & 2007 & $\begin{array}{l}\text { International Journal of } \\
\text { Management Reviews }\end{array}$ & 2425 \\
\hline Carter, Craig R.; Rogers Dale S. & $\begin{array}{l}\text { A framework of sustainable } \\
\text { supply chain management: } \\
\text { moving toward new theory }\end{array}$ & 2008 & $\begin{array}{l}\text { International Journal of } \\
\text { Physical Distribution and } \\
\text { Logistics Management }\end{array}$ & 1756 \\
\hline
\end{tabular}


Table 2. Cont.

\begin{tabular}{|c|c|c|c|c|}
\hline Authors & Title & Year & Journal & Citation \\
\hline Rao, Purba; Holt, Diane & $\begin{array}{l}\text { Do Green Supply Chains Lead } \\
\text { To Competitiveness And } \\
\text { Economic Performance? }\end{array}$ & 2005 & $\begin{array}{l}\text { International Journal of } \\
\text { Operations and Production } \\
\text { Management }\end{array}$ & 1402 \\
\hline Sarkis, Joseph & $\begin{array}{l}\text { A strategic decision framework } \\
\text { for green supply chain } \\
\text { management }\end{array}$ & 2003 & $\begin{array}{l}\text { Journal of Cleaner } \\
\text { Production }\end{array}$ & 1268 \\
\hline $\begin{array}{l}\text { Gungor, Askiner; Gupta, } \\
\text { Surendra M. }\end{array}$ & $\begin{array}{l}\text { Issues in environmentally } \\
\text { conscious manufacturing and } \\
\text { product recovery: a survey }\end{array}$ & 1999 & $\begin{array}{l}\text { Computers and Industrial } \\
\text { Engineering }\end{array}$ & 1137 \\
\hline $\begin{array}{l}\text { Fleischmann, Mortiz; Krikke, Hans } \\
\text { Ronald; Dekker, Rommert; Flapper, } \\
\text { Simme Douwe P. }\end{array}$ & $\begin{array}{l}\text { A characterisation of logistics } \\
\text { networks for product recovery }\end{array}$ & 2000 & Omega & 1012 \\
\hline
\end{tabular}

The next stage of this content analysis, category selection and material evaluation were defined and evaluated based upon the content's analytical and structural dimensions. The results are provided in the following.

\section{Research Methodology}

In order to extract meaningful information, the articles were divided into six categories as provided in Table 3.

Table 3. Main classifications of the papers.

\begin{tabular}{|c|c|c|c|c|c|}
\hline ECLO Dimension & $\begin{array}{l}\text { Research } \\
\text { Methodology }\end{array}$ & Modeling Approach & Sustainability & Sustainability Dimensions & Industry \\
\hline $\begin{array}{l}\text { SSCM/GSCM/ } \\
\text { CLSCM/Low-carbon } \\
\text { logistics/Waste } \\
\text { management }\end{array}$ & $\begin{array}{l}\text { Conceptual } \\
\text { model/Quantitative } \\
\text { modeling/Empirical } \\
\text { analysis/Case } \\
\text { study/Literature } \\
\text { review }\end{array}$ & $\begin{array}{l}\text { Mathematical } \\
\text { programming/MCDM/Fuzzy } \\
\text { sets/Heuristics/Simulation/ } \\
\text { Game Theory/Hybrid } \\
\text { methods }\end{array}$ & Yes/No & $\begin{array}{l}\text { Economic/ } \\
\text { Environmental/Social }\end{array}$ & $\begin{array}{l}\text { Food/Electronics/ } \\
\text { Construction etc. }\end{array}$ \\
\hline
\end{tabular}

The following sections detail the iterative stages of category analysis and material evaluation that include ECLO dimensions, research methodologies, quantitative modeling approaches and fuzzy tools, and industry classifications.

Although the integration of environmental, economic, and social dimensions provides a clear understanding of complex issues [27,31], sustainability can be examined by either one, two, or three dimensions. Here, the articles that focus on environmental sustainability were reviewed and analyzed while purely economic or social, or socio-economic studies were excluded. Referring to Seuring and Müller [10] and Seuring [27], the papers were first categorized according to their environmental, economic, and social sustainability dimensions. Out of 707 papers, 273 articles discussed all three dimensions in which 228 of these contained the term of "Sustainability". Even though the term is not mentioned, sustainability is addressed in all papers that include environmental, economic, and social dimensions. Figure 5 shows the annual distribution of the papers according to their sustainability dimensions. As illustrated in Figure 5, the publications on sustainability show a significant growth in the last decade. 


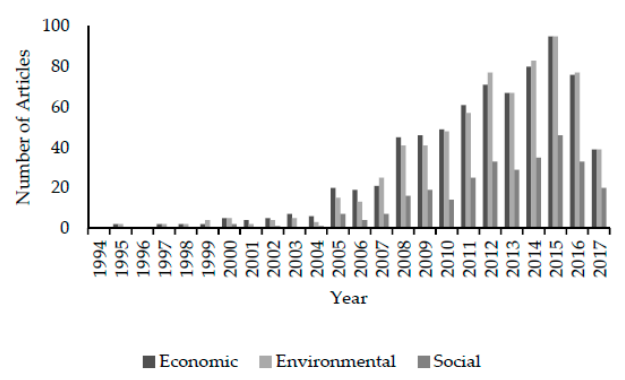

Figure 5. Annual distribution of the papers across sustainability dimensions.

\subsection{ECLO Dimensions}

Farahani et al. [39] stated that supply chain operations should be implemented in order to minimize the total cost, and to make the network more flexible and responsive against environmental and social changes. As described in Section 1, environmentally concerned logistics operations (ECLO) is formed through five structural dimensions of SSCM, GSCM, CLSCM, low-carbon logistics, and waste management. Among these, SSCM is accepted as a broader field. The relationship between these dimensions and their subfields are depicted in Figure 6. Different terms of the same subfield are grouped around the related dimensions, i.e., greenhouse gas or carbon emission instead of low-carbon logistics.

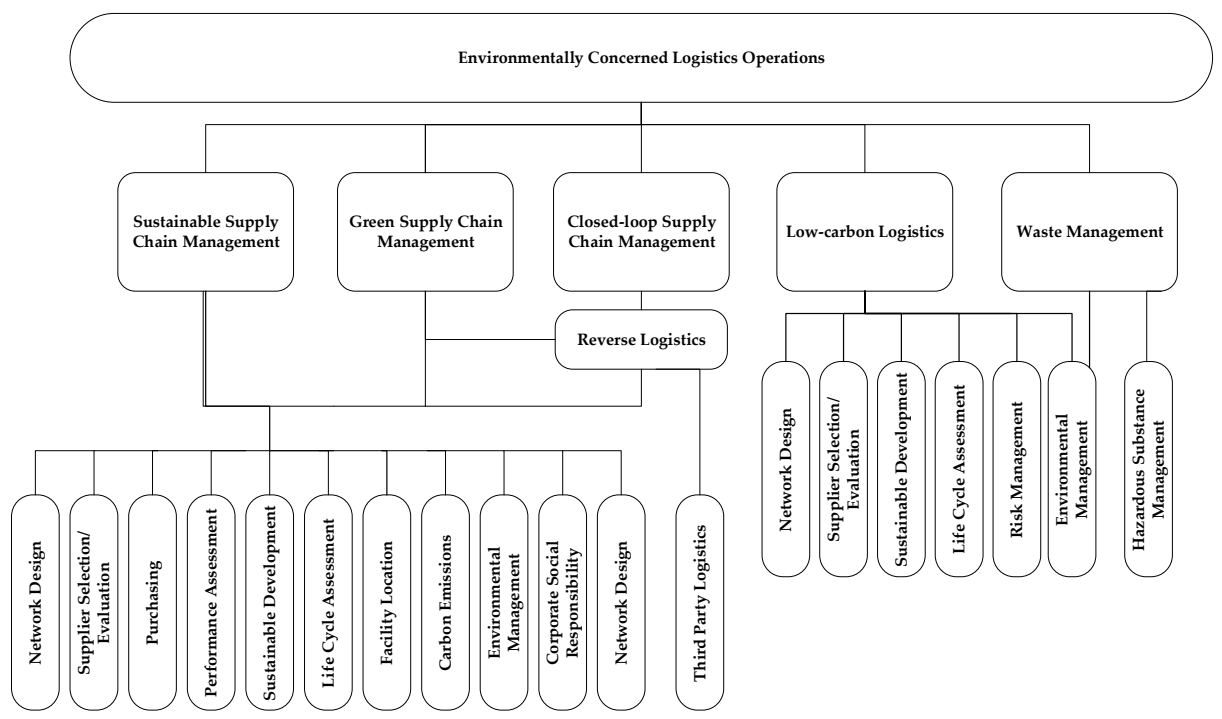

Figure 6. The relationship between environmentally concerned logistics operations (ECLO) drivers with their subfields.

Figure 7, below, depicts the percentages of paper categorization of ECLO dimensions. Detailed analysis of each structural dimensions of ECLO is provided in the following sections.

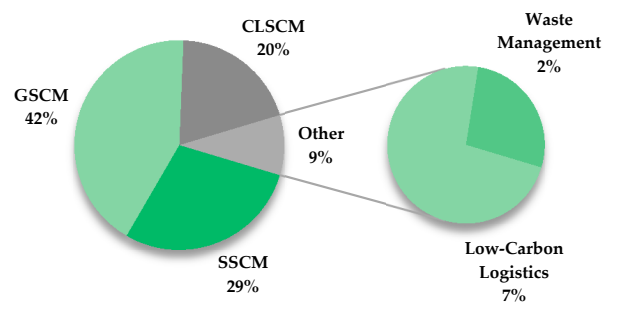

Figure 7. The percentages of paper categorization of ECLO dimensions. 


\subsubsection{Sustainable Supply Chain Management}

In the last decades, related studies considered optimal supply chain network design and incorporated both environmental and social aspects into the economic dimension. Ahi and Searcy [11] indicated that the literature offered a total of 12 unique definitions for SSCM. According to their research, the most accepted definition was initially introduced by Seuring and Müller [10], who defined SSCM as "the management of material, information and capital flows as well as cooperation among companies along the supply chain while taking goals from all three dimensions of sustainable development, i.e., economic, environmental and social- into account which are derived from customer and stakeholder requirements". However, Ahi and Searcy [11] also found that some of the definitions of SSCM address only two dimensions. Similarly, Seuring [40] emphasized the two important SSCM dimensions as environmental and social. Accordingly, Frota Neto et al. [41] described sustainable logistics as the balance of environmental and economic aspects. Therefore, it is evident that there is a consensus on accepting environmental considerations as an integral part of SSCM.

In this analysis, we found that 217 papers classified as SSCM. The number of SSCM articles across primary journals on SSCM from 1994 to 2017 are provided in Figure 8a,b, respectively. Figure 8a illustrates the widely respected JCLP journal as the one journal that encourages the SSCM papers with the IJPE journal following a close second. In addition, Figure $8 \mathrm{~b}$ represents the number of SSCM publications reach its peak in 2012. Even though a slight decline occurred in 2013 and 2016, it is clear that the number of SSCM papers increased steadily over the years. Figure $8 \mathrm{c}$ depicts the number of SSCM papers across SSCM practices that mainly include supplier selection/evaluation, performance measurement/assessment, corporate social responsibility, facility location/allocation, life cycle assessment, network design, and carbon emissions. Here, although sustainable development is the most published subfield of SSCM, network design and supplier selection/evaluation are ranked second and third.

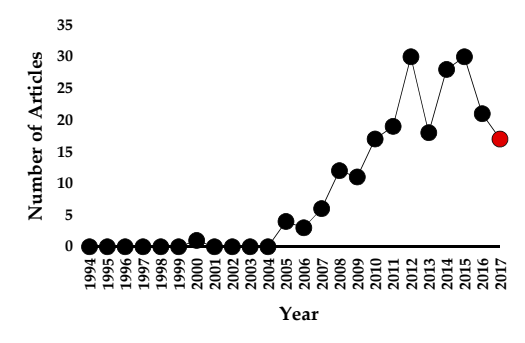

(a)

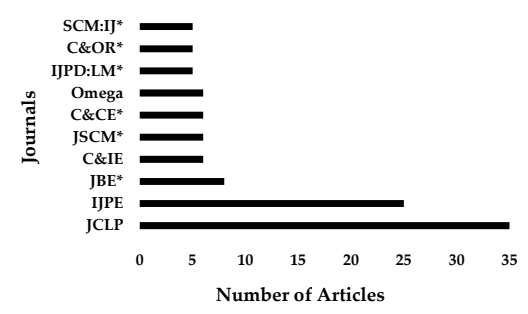

(b)

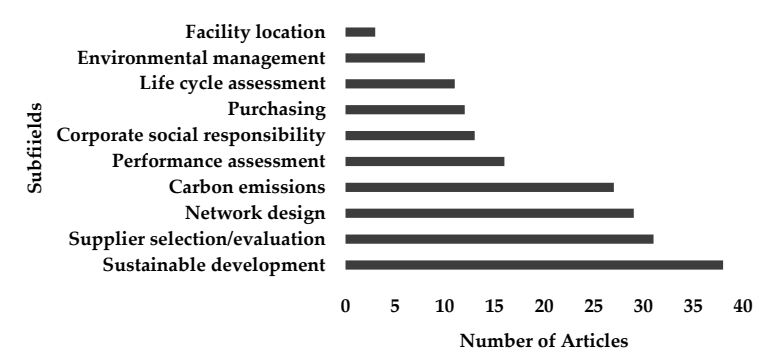

(c)

Figure 8. * (C\&OR: Computer and Operations Research; IJPD\&LM: International Journal of Physical Distribution and Logistics Management; JSCM: Journal of Supply Chain Management; SCM\&IJ: Supply Chain Management and An International Journal; C\&CE: Computers and Chemical Engineering; JBE: Journal of Business Ethics). Distribution of SSCM papers across formal aspects. (a) Number of SSCM articles from 1994 to 2017; (b) Number of SSCM articles across primary journals; (c) Number of SSCM articles across SSCM subfields. 


\subsubsection{Green Supply Chain Management}

Srivastava [20] defined GSCM as "integrating environmental thinking into supply-chain management, including product design, material sourcing and selection, manufacturing processes, delivery of the final product to the consumers as well as end-of-life management of the product after its useful life". In the literature, the term GSCM is studied under different keywords such as green logistics, environmental SCM, environmental logistics, and cleaner SCM. GSCM includes a wide-range of topics from forward logistics to reverse logistics [2,16,20,39,42-44]. In this regard, Rao and Holt [45] and Govindan et al. [46] claimed that GSCM practices embody the entire supply chain processes that begins with the manufacturer and ends with the customer. These GSCM practices includes reverse logistics, green design, green purchasing, carbon management, and integration of product life cycle.

According to the literature survey conducted by Ahi and Searcy [11], GSCM depicts sustainability characteristics, whereas, the environmental dimension of sustainability focuses on GSCM. It is evident that the integration of the environmental and economic criteria is delineated as green criteria or green sustainability in the literature $[2,11,47]$. In this analysis, the $66 \%$ of the GSCM related manuscripts take into account two dimensions, $22 \%$ of the manuscripts factor in study all of the three dimensions, and the remaining $12 \%$ address only the environmental dimension. According to these results, GSCM optimizes environmental and economic dimensions and should be classified SSCM.

The distribution of the GSCM according to formal aspects is depicted in Figure 9, where the distributions of the GSCM papers found in primary journals and years published shown in Figure 9a,b, respectively. The number of the articles based on according to GSCM main subfields is given in Figure 9c. Within this data, Figure 9a presents JCLP as the leading journal on GSCM followed by IJPE. When comparing the field of SSCM to GSCM, it is clear that IJPE and JCLP publish the most articles about these fields. Additionally, Figure $9 \mathrm{~b}$ demonstrates a surge in the number of the GSCM articles between 2006 and 2017.

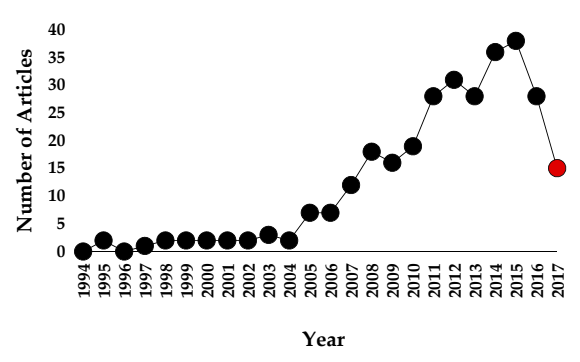

(a)

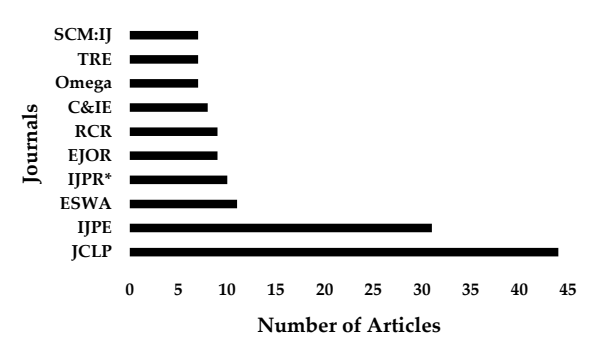

(b)

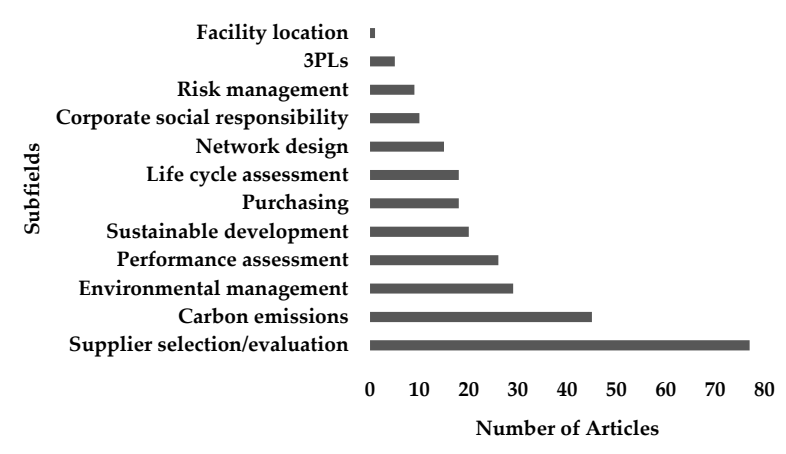

(c)

Figure 9. * (IJPR: International Journal of Production Research) Distribution of GSCM papers across formal aspects. (a) Number of GSCM articles from 1994 to 2017; (b) Number of GSCM articles across primary journals; (c) Number of GSCM articles across GSCM subfields. 
The wide scope of GSCM covers a variety of subfields that include facility location to supplier selection/evaluation, where supplier selection/evaluation is the most studied subfield (Figure 9c). Accordingly, the least preferred subfield is the facility location/allocation-related issues. Figure $9 \mathrm{c}$ further shows that various papers on sustainable development of GSCM encompass all three dimensions of sustainability.

\subsubsection{Closed-Loop Supply Chain Management}

CLSCM embodies all of the processes of product recovery including reverse logistics, product disposition, remanufacturing, recycling, reuse, and refurbishing [16,20]. CLSCM is defined by Guide and Van Wassenhove [48] as "the design, control, and operation of a system to maximize value creation over the entire life cycle of a product with dynamic recovery of value from different types and volumes of returns over time". Since CLSCM addresses reverse logistics as well as remanufacturing, recycling and reuse of end-of-life products, there is not a consensus on combining CLSCM and SSCM in the literature. Although Taticchi et al. [49] state that SSCM encompasses the entire process of the product life cycle, Brandenburg and Rebs [7] point out that these two concepts can partly be combined in definition. Furthermore, they indicate that SSCM and CLSCM are examined differently according to the preferred research methodologies. A variety of papers studies SSCM or GSCM from only forward logistics perspective $[3,7,10,31]$, while some consider SSCM as the combination of reverse and forward logistics flows [2,20,50-52]. Additionally, various papers in the literature acknowledge that closing the loop with reverse logistics is a green practice $[19,25,45,46,53,54]$.

Since forward logistics flows are known as the management of downstream material flows, reverse logistics flows are defined as the management of upstream material flows [10,55]. Ilgin and Gupta [1] indicated that CLSCM is simultaneously controlled by upstream and downstream channels; whereas Guide and Van Wassenhove [48] stated that reverse material flows dominate the forward supply chains within CLSCM operations. Reverse logistics, which is also described as reverse SCM, is part of the process that collects used materials within CLSCM aimed at maintaining environmental sustainability within SCM [6,56,57]. Kongar et al. [57] emphasized that reverse logistics activities focus on finding environmentally, economically, and socially sustainable solutions through the transparency of information with regards to the logistics flows. Fleischmann et al. [55] further highlighted that reverse logistics is the sustainable management of upstream flows, while Agrawal et al. [38] emphasized that reverse logistics is vital for sustainable competitiveness. Hence, it can be deduced that reverse logistics also encompasses economic sustainability. Existing literature surveys discuss SSCM related literature while excluding CLSCM. Unlike these existing studies, this paper includes reverse logistics operations of CLSCM research for remanufacturing, reuse, and/or refurbishing. Furthermore, this paper recognizes the field of CLSCM within the field of SSCM. However, manufacturing-intensive papers that discuss solely the operational aspects of CLSCM were not included.

The number of CLSCM articles based on formal aspects is presented in Figure 10. In this regard, the number of the CLSCM related papers according to the top ten journals over the past 24 years are depicted in Figure 10a,b, respectively. According to the figures, JCLP, EJOR, C\&IE and Omega are the major journals on CLSCM with JCLP being the leading journal. Furthermore, a rapid growth in the number of journals on the subject of CLSCM begins in 2006 and peaks in during 2013 and 2016.

The most influential topics in CLSCM are presented in Figure 10c. According to the subfield analysis, reverse logistics is the most popular subfield with network design a close second. Additionally, the subfield of sustainable development is identified as a field that lacked attention indicating a gap in the related literature. 


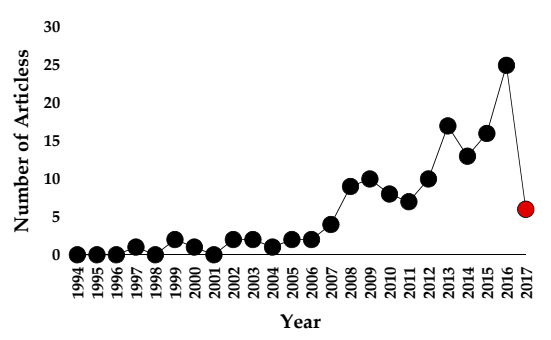

(a)

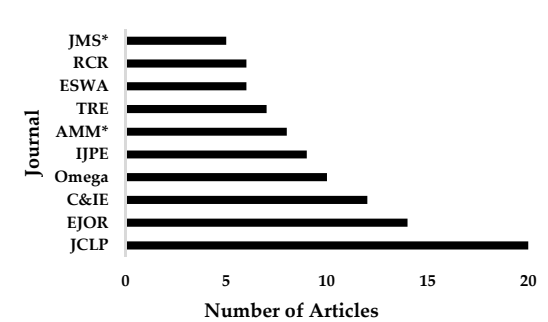

(b)

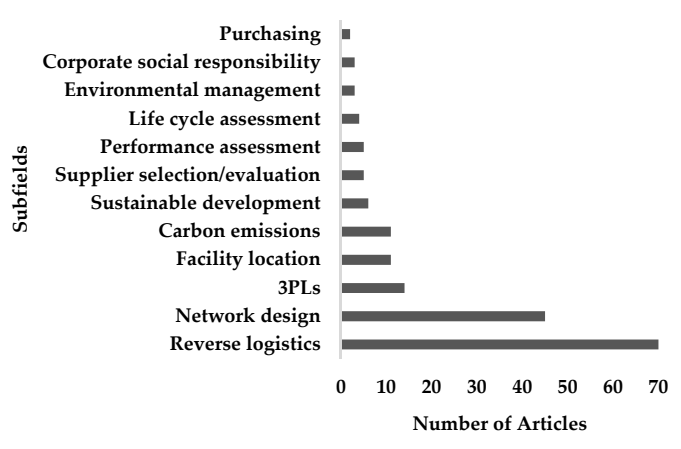

(c)

Figure 10. * (JMS: Journal of Manufacturing Systems; AMM: Applied Mathematical Modelling). Distribution of the CLSCM papers across formal aspects. (a) Number of CLSCM articles across primary journals; (b) Number of CLSCM articles from 1994 to 2017; (c) Number of CLSCM articles across CLSCM subfields.

\subsubsection{Low-Carbon Logistics and Waste Management}

The articles that focus on low-carbon logistics are studied as a subfield of GSCM, SSCM, or CLSCM [52,58-60]. Figures 7c, 8c and 9c reflect the scope of SSCM, GSCM, and CLSCM practices. These figures indicate that carbon emissions is a topical subfield in environmentally focused logistics operations. Some papers define low-carbon optimization as a green practice $[54,59,61,62]$. Low-carbon logistics exists in different forms in the literature such as greenhouse gas emissions, carbon emissions, $\mathrm{CO}_{2}$ emissions, carbon footprints, and carbon management. Igarashi et al. [62] defined low-carbon logistics as the visualization and reduction of $\mathrm{CO}_{2}$ emissions that are achievable through the entire supply chain that extend beyond a single organization. In addition, they further studied a design for lower disassembly cost, higher recycling, and $\mathrm{CO}_{2}$ saving rates by an environmental and economic parts selection. Similarly, low-carbon logistics models were examined by using the word "eco-efficiency" or "eco-driving". Here, the focus of the articles included energy efficient transportation, low fuel consumption, and high usage of green fuels [53].

One essential factor of sustainability is low-carbon logistics [63]. Sundarakani et al. [59] underlined that integrating low carbon emissions into SCM increases the use of energy efficient vehicles, and also minimizes waste pollution by increasing the volume of recycling. The majority of the various models that individually study carbon emissions without integrating the topic into SSCM, GSCM or CLSCM focus on environmental and social sustainability. The remaining papers involve either environmental and economic aspects of sustainability or all three dimensions. Therefore, these models can be accepted as a narrow form of sustainable development and can be considered as part of SSCM.

Location selection for hazardous waste storage and efficient transportation of waste are two problems that are commonly studied in waste management research [64]. In this research, the manuscripts that focus solely on logistics operations within waste management are considered part of ECLO research. The goal of these models is to reduce environmentally hazardous substances and energy usage. The majority of articles on the topic of waste management also included topics such as 
low-carbon logistics, GSCM, CLSCM, or SSCM where the transportation of waste materials and energy savings were considered. For the purpose of sustainability, waste management is also an indicator of sustainable development $[6,19,65-67]$. In this analysis, waste management models that discussed only product recovery were excluded.

Through this research, it is found that the number of individually studied papers in these two fields comprises of only a small portion of the overall sample of 707 papers. Furthermore, it can be claimed that the studies on low-carbon logistics and logistics focused on waste management are correlated and should be considered as subsets of GSCM or CLSCM activities. Figure 11a demonstrates the distribution of papers on the fields of low-carbon logistics and waste management included in top journals. This figure shows that IJPE included the most articles about low-carbon logistics; whereas, JCLP published the largest number of articles on waste management. Furthermore, Figure 11b depicts the distribution of papers on low-carbon logistics and waste management from 1994 to 2017. The figure illustrates an increase in 2011 and 2015 of low-carbon logistics papers. Contrary to the linear movement of articles in low-carbon logistics, papers that discussed the field of waste management with logistics concentration tends to remain stable over the years and points out a gap in the literature. Figure 11c depicts the distribution of the papers according to subfields of low-carbon logistics and waste management. As observed from the figure, even though it is evident from Figure 11c that the subfield of network design is the leading subtheme, articles on sustainable development and life cycle assessment also contributes to substantial number of papers on low-carbon logistics. Additionally, Figure 11c shows that hazardous substance management is the most frequent subfield on logistics related waste management. Even though the analysis on waste management is comprehensive; it was not exhaustive. The query search on waste management related articles were exclusive to logistics research.

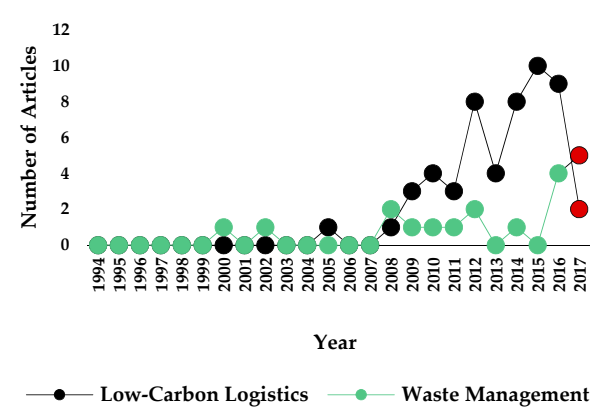

(a)

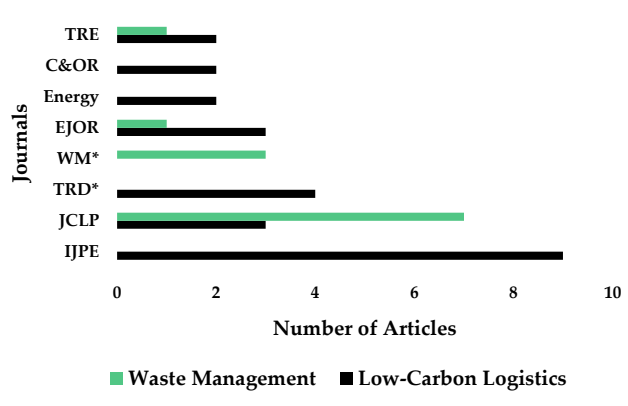

(b)

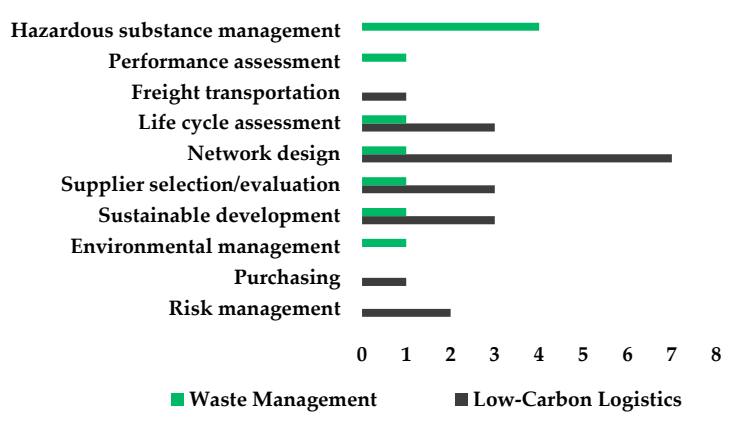

(c)

Figure 11. * (WM: Waste Management). Distribution of the low-carbon logistics and waste management papers across formal aspects. (a) Number of articles on low-carbon logistics and waste management from 1994 to 2017; (b) Number of articles on low-carbon logistics and waste management across primary journals articles; (c) Number of articles across subfields of low-carbon logistics and waste management. 


\subsection{Research Methodology}

In this analysis, research methods utilized in the related literature were divided into five categories: the conceptual/theoretical model, quantitative modeling, empirical analysis, case study, and literature review. The number of papers across these research five methodologies is shown in Figure 12. Some of the 707 papers discuss a combination of methodologies that include conceptual/theoretical model and case study $(5 \%)$, conceptual/theoretical model and empirical analysis (13\%), conceptual/theoretical model and literature review (2\%), literature review and case study $(1 \%)$, literature review and empirical analysis $(1 \%)$, quantitative modeling and case study (74\%), quantitative modeling and empirical analysis $(4 \%)$, and quantitative modeling and literature review (1\%). Therefore, implementing a case study in quantitative model-based research is found as the most preferred approach in ECLO focused papers.

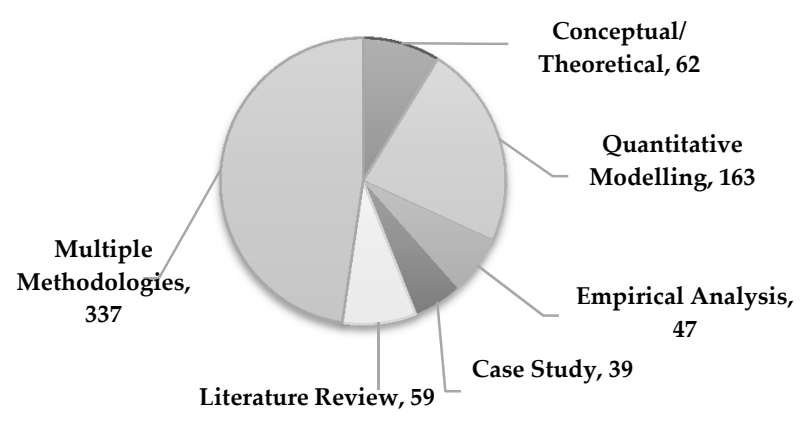

Figure 12. Number of the ECLO papers across research methods.

Furthermore, these research papers were analyzed and categorized according to their research methodologies for each field of ECLO. The most preferred research method on SSCM emerged from quantitative modeling papers, where 100 out of 217 papers employed quantitative modeling and case study, followed by conceptual/theoretical model papers. Furthermore, the major research methodology implemented in the GSCM papers also quantitative modeling involving 176 out of 282 papers. Similarly, 120 out of 121 papers are found that apply quantitative modeling to CLSCM where hypothetical models constituted the majority of these studies. These results show that, SSCM concept is mainly discussed over its conceptual perspective, while GSCM and CLSCM are primarily studied by quantitative modeling methodologies.

The remainder of this section focuses on the classification of quantitative models, where the fuzzy-based models and decision making models are detailed.

\subsubsection{Quantitative Models}

In this paper, quantitative modeling techniques include operations research tools such as mathematical programming, decision analysis, heuristics, simulation, and others. Conversely, statistical models that include structural equation modeling, Delphi study, hierarchical linear modeling, regression analysis, and the Taguchi method were excluded from the quantitative model class.

Figure 13 provides a basic framework of the analysis and depicts each model with its corresponding sub-classes $[3,18,68]$.

In total, 425 out of 707 papers were labeled as quantitative modeling papers. These papers were then separated based on their designated class in accordance with the constructed framework (Table A2 in Appendix A).

Using the framework provided in Figure 13, mathematical models were categorized into single-objective models and multi-objective optimization (MOP) models. These models include linear programming (LP), nonlinear programming (NLP), mixed integer programming (MIP), mixed integer linear programming (MILP), goal programming (GP), robust programming (RP), stochastic 
programming (SP), dynamic programming (DP), possibilistic programming, queuing theory, fuzzy mathematical programming, and bi-objective programming [58,69-75].

Typically, in quantitative modeling techniques, heuristics are combined with other methodologies. Within this research, it is also determined that heuristics present a viable solution methodology when used with additional methods. Furthermore, heuristics can be categorized under two main classes referred as exact heuristics and meta-heuristics. In addition, neural network (NN) models can also be included under the umbrella of heuristics [3]. With this reasoning, this paper categorized heuristics under three classes as follows: exact heuristics, meta-heuristics, and NN.

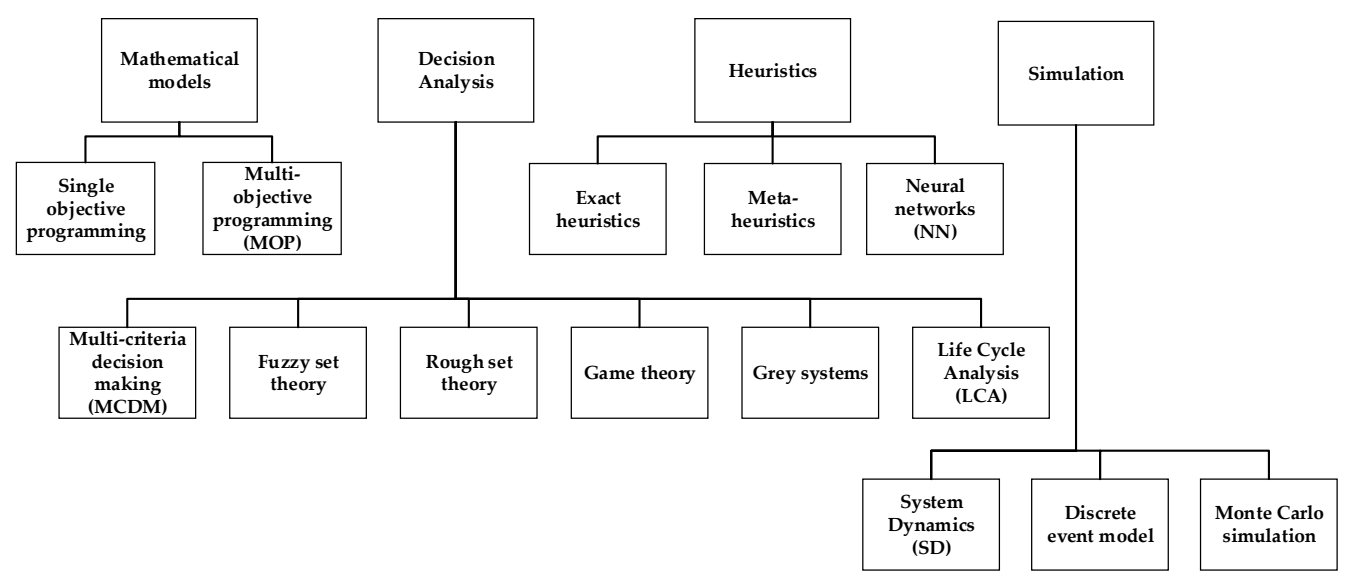

Figure 13. A basic framework of the modeling techniques.

It is also observed that limited number of papers discussed simulation models. In this regard, system dynamics is included in 3 papers [76-78], whereas discrete event simulation models and Monte Carlo simulation models are utilized in 4 and 3 papers, respectively [79-84].

Various decision analysis methods include multi-criteria decision making, fuzzy set theory, rough set theory, game theory, grey systems, and life cycle analysis. For the purpose of the content analysis, papers that addressed sustainability through the use of fuzzy logic were considered. When various papers on decision analysis were compared, it is found that several papers cross-referenced fuzzy set theory and rough set theory with artificial intelligence techniques $[3,23]$. Additionally, various papers discuss fuzzy set theory as an individual methodology in decision making [85-87], while the vast majority of papers integrates fuzzy approaches into multi-criteria decision making (MCDM) [88-94]. This paper examines fuzzy sets as one of the decision analysis tools, and divided these approaches into the sub-techniques depicted in Figure 14.

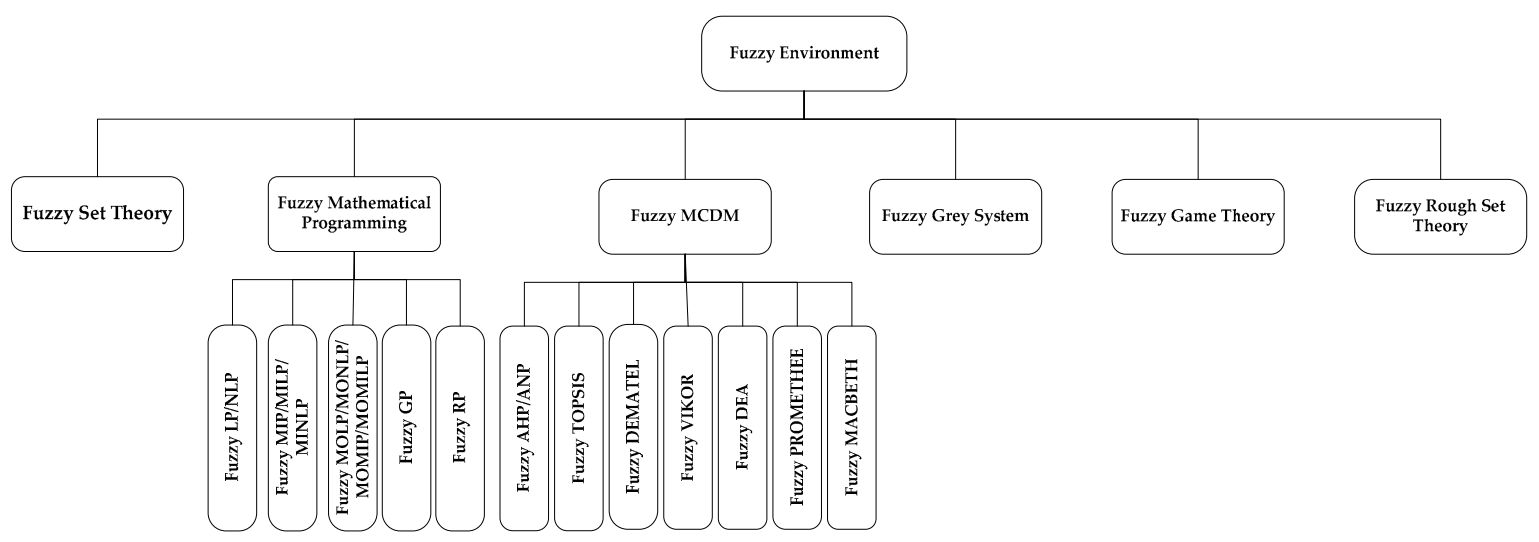

Figure 14. Classification of fuzzy methods with techniques. 
Here, out of the 156 quantitative modeling papers that employ fuzzy techniques only 9 of them focus on fuzzy sets as the only method. The remaining papers propose hybrid approaches that combine the theory with various modeling techniques such as MCDM, mathematical modeling, rough sets, grey systems, and game theory. In this regard, the classification of these papers depends upon on each technique. It is also found that the majority of papers using fuzzy approaches is primarily correlated with MCDM, followed by mathematical programming. More specifically, the fuzzy MCDM approach constitutes 96 out of the 147 fuzzy papers, while fuzzy mathematical programming is used in 53 out of the 147 fuzzy papers. The remaining papers discuss other fuzzy related methods such as fuzzy rough sets, fuzzy game theory, and fuzzy grey systems. In an effort to further understand the relationship between fuzzy sets and its utilization in ECLO fields and subfields, a relationship matrix is generated as illustrated in Figure 15. Moreover, Table A3 (Appendix A) further explains the classifications of each ECLO topic and the applied industry in focus. A detailed analysis of fuzzy focused approaches is provided in Section 4.2.2.

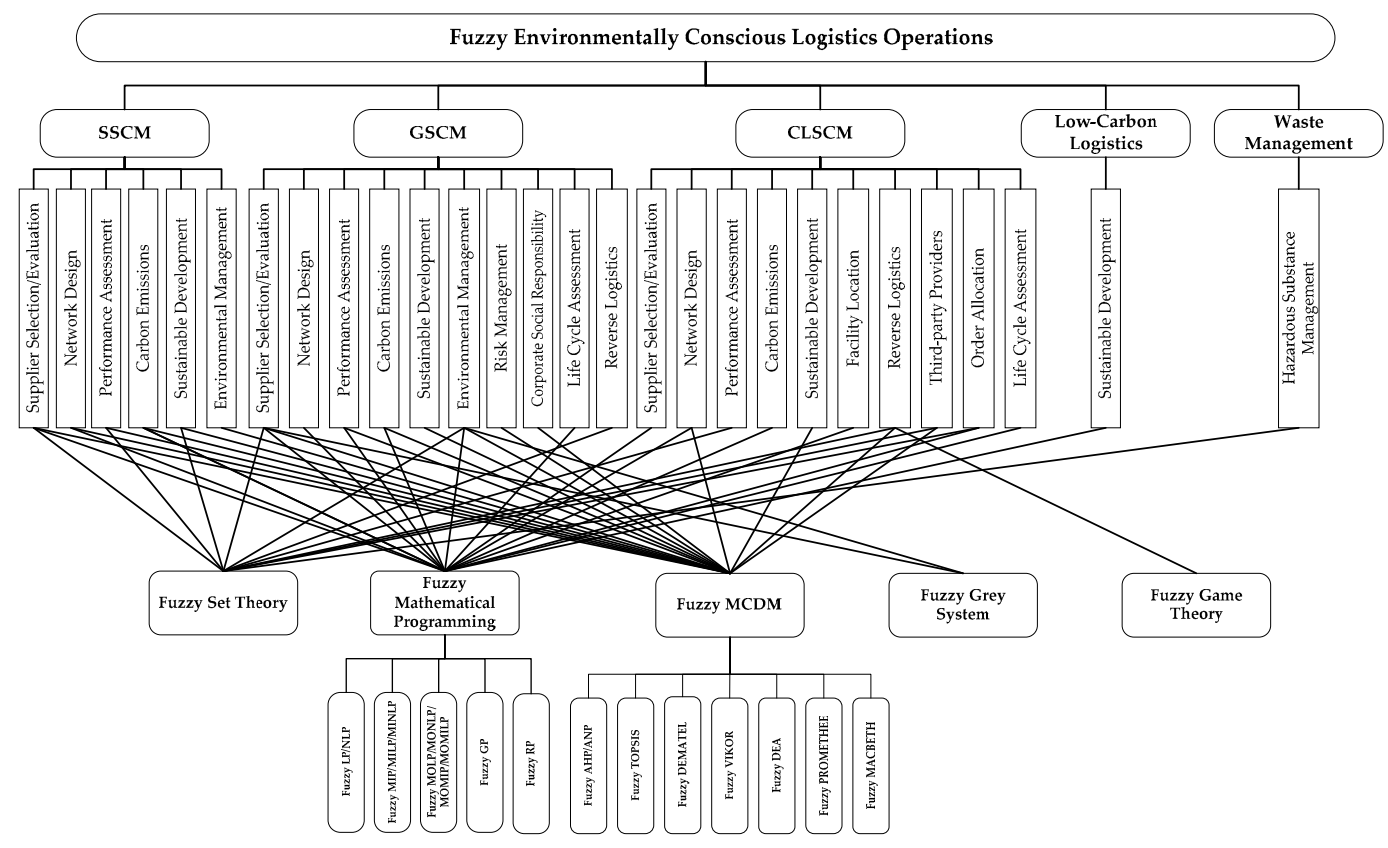

Figure 15. Distribution of the ECLO fields and subfields across fuzzy methods.

An analysis of the research gaps in fuzzy-based literature is provided in the following.

\subsubsection{Fuzzy Set Theory}

Zadeh [95] defined fuzzy set theory as "a class of objects with a continuum of grades of membership in which where human-thinking plays an important role, whereby uncertainty in the classes of objects is taken into consideration by using the linguistic terms and membership functions". Olugu and Wong [96] defined fuzzy set theory as a knowledge and concept utilization process based on human reasoning. The literature presented a variety of fuzzy focused papers that introduced fuzzy logic as defining membership functions, incomplete preference relationships and linguistic preferences, applying fuzzy arithmetic, fuzzy entropy and fuzzy c-means clustering, utilizing intuitionistic fuzzy sets, fuzzy logic controllers, defining interpretive ranking processes, fuzzy inference systems, fuzzy rule-based systems, and fuzzy axiomatic design (Table A2) [94,97-100].

Furthermore, Amindoust et al. [85] studied the sustainable supplier selection problem through a new ranking model based on fuzzy inference system. In their paper, the degree of importance of supplier selection criteria and sub-criteria were evaluated with regards to the decision makers' opinion. Similarly, Ghadimi and Heavey [87] investigated a sustainable supplier evaluation and 
selection model by using fuzzy inference systems. The approach that Humphreys et al. [86] used to examine the supplier assessment process was to implement a user-centered hierarchical fuzzy membership functions with a focus on environmental criteria. In addition, Olugu and Wong [96] presented a performance evaluation system for CLSCM by processing an expert fuzzy rule-based model using Visual Basic.Net. Govindan and Murugesan [101] proposed a fuzzy extent analysis on a 3PL reverse logistics provider selection problem. Another approach was used by Kannan et al. [102] was a fuzzy axiomatic design (FAD) approach in order to select the best green supplier in the system.

Figure 16a,b depict the top ten journals and publication years of fuzzy approach ECLO papers, respectively. Here, the most preferred journal is the Journal of Cleaner Production (JCLP), where the amount of papers on fuzzy-related ECLO topics remain stable in numbers until 2005. Then, the ECLO articles increased in growth in the beginning of 2010 reaching their peak in 2016 due to the increased attention of environmental concerns.

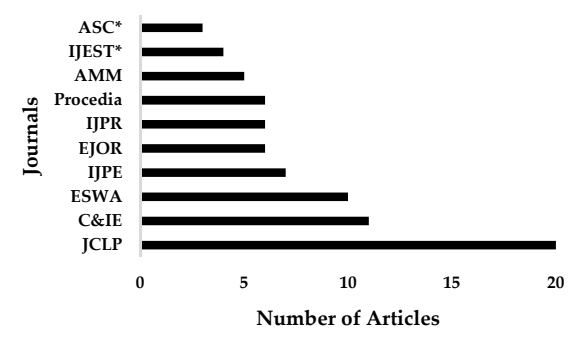

(a)

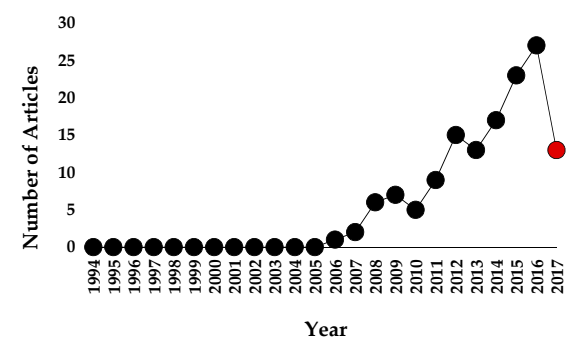

(b)

Figure 16. * (ASC: Applied Soft Computing; IJEST: International Journal of Environmental Science and Technology). Distribution of fuzzy-related ECLO papers across top ten journals and years. (a) Number of fuzzy-based ECLO articles across top ten journals; (b) Number of fuzzy-based ECLO articles across years.

Fuzzy Mathematical Programming

Fuzzy mathematical modeling papers include both single-objective and multi-objective models wherein fuzzy LP/NLP, fuzzy MIP/MILP/MINLP, fuzzy RP, fuzzy GP, fuzzy DP, fuzzy MOP/MOLP, fuzzy bi-objective programming, and fuzzy SP are applied. Possibilistic programming is also identified as a fuzzy mathematical programming approach where possibilistic distributions are implemented to define the model parameters [103]. In the literature, the manuscripts which include fuzzy mathematical modeling constitute 53 out of the 156 fuzzy-based articles.

Among these, Shaw et al. [89] combined a hybrid method using fuzzy AHP and fuzzy MOLP to solve the supplier selection problem in order to optimize a low-carbon logistics network. Similarly, Kannan et al. [104] applied a combination of fuzzy AHP, fuzzy TOPSIS, and fuzzy MOLP models to identify the green supplier selection and order allocation problem. Furthermore, Subulan et al. [105] studied a multi-echelon, multi-product, and multi-period tire closed-loop supply chain network design model using multi-objective interactive fuzzy goal programming method. When Vahdani et al. [75] constructed a reliable CLSC network design model, they used a hybrid method of robust optimization and bi-objective fuzzy queuing mixed integer linear programming. The following year, Vahdani et al. [106] studied the reliable CLSC network design model by implementing a bi-objective fuzzy possibilistic-queuing mixed integer linear programming model. In addition, Amin and Zhang [107] proposed a multi-objective mixed integer linear programming and fuzzy set theory in order to optimize the CLSC and the supplier selection process.

\section{Fuzzy Multi-Criteria Decision Making}

Multi-criteria decision making (MCDM) is known as an operations research method that evaluates multiple alternatives in order to obtain meaningful results in a complex decision making 
environment. Various MCDM approaches include Analytic Hierarchy Process/Analytic Network Process (AHP/ANP), Decision Making Trial and Evaluation Laboratory (DEMATEL), Technique for Order Performance by Similarity to Ideal Solution (TOPSIS), Vlse Kriterijumska Optimizacija Kompromisno Resenje' (VIKOR) (the English translation of VIKOR is Methodology of Multi-criteria Optimization and Compromise Solution), Data Envelopment Analysis (DEA), Preference Ranking Organization method for enrichment evaluations (PROMETHEE), Measuring Attractiveness by a Categorical Based Evaluation Technique (MACBETH), Multi-attribute Utility Theory (MAUT), and weighted product/sum model. It is found that the papers that discussed various MCDM approaches constitute 181 out of 425 quantitative modeling papers, where 132 out of the 181 papers integrated other modeling approaches such as fuzzy sets, mathematical programming, heuristics, and/or simulation. Table A4 (Appendix A) represents the classification of each MCDM approach with regards to ECLO topics and its subfields. As seen in Table A4, the most utilized MCDM method is AHP/ANP, while the most studied subfield is supplier selection/evaluation.

In the reviewed literature, fuzzy sets are mostly integrated into the multi-criteria decision making approaches $[23,78,92,99]$. Here, the fuzzy-involved MCDM methods contain fuzzy ANP/AHP, fuzzy DEMATEL, fuzzy TOPSIS, fuzzy VIKOR, fuzzy DEA, fuzzy PROMETHEE, and fuzzy MACBETH. The total number of papers that applied fuzzy MCDM techniques constitutes 97 out of 156 fuzzy papers. Therefore, fuzzy sets are mainly integrated into MCDM. Furthermore, upon additional analysis, 54 out of the 97 fuzzy MCDM papers preferred the fuzzy AHP/ANP approach, 22 out of the 97 papers used fuzzy TOPSIS approach, and 13 out of the 97 papers followed fuzzy DEMATEL approach. The remaining 13 papers contain other fuzzy MCDM methods such as fuzzy VIKOR (5), fuzzy DEA (5), fuzzy PROMETHEE (2) and fuzzy MACBETH (1). It should be noted that the inequalities between total number of papers on fuzzy MCDM is based on the hybrid studies that combines two or more MCDM approaches.

\section{Fuzzy AHP/ANP}

Two commonly used MCDM tools are AHP and ANP methods. In the literature, these methods preferred in evaluating qualitative data when compared to the other models such as mathematical programming [65]. Saaty [108] introduced AHP model that enables the decision maker to integrate and evaluate qualitative and quantitative criteria and sub-criteria by building a one-way hierarchical structure among decision levels. ANP [109], which is an extension of AHP, contains a network structure that deals with more complex relationship by disregarding a strict hierarchical structure [91,110-112]. In other words, AHP assumes independence between each criterion, whereas ANP introduces dependence and feedback among the criteria $[90,91,111,113]$. In the quantitative literature, the majority of papers on AHP/ANP methods are combined with fuzzy sets since fuzzy set theory incorporates the uncertainty of human judgement into the decision-making process for more effective and realistic modelling [112,113]. Moreover, fuzzy AHP/ANP models help detect environmental criteria weights where the majority of environmental criteria involves linguistic terms and imprecise judgements [111].

As for the distribution of these manuscripts, 54 out of the 97 papers employ fuzzy AHP/ANP method. While AHP is the most preferred method in the ECLO subfields compared to ANP, both of the approaches are the leading methods of MCDM. Specifically, AHP is a widely used MCDM technique, where it is integrated as an additional methodology into the majority of other MCDM models. More specifically, it is observed that the majority of the papers on supplier selection/evaluation in the literature applied either solely AHP/ANP or AHP/ANP integrated hybrid approaches, which is an evident that it is the best suitable approach on solving supplier selection/evaluation models. Efendigil et al. [114] investigated a holistic approach based on ANN and fuzzy AHP (FAHP) methods in order to select the most appropriate and desirable third-party reverse logistics service provider in consideration of various subjective requirements. Shaw et al. [89] presented a hybrid approach based on FAHP and fuzzy MOLP in a supplier selection problem for a low-carbon supply chain. Similarly, 
Kannan et al. [104] developed an integrated approach based on FAHP and MOP for a green supplier selection and order allocation model for a multiple sourcing problem.

Büyüközkan and Çifçi [88] presented a novel approach based on fuzzy ANP under incomplete preference relations for an effective sustainable supplier selection problem. Their proposed solution was applied in a white good industry case study. Büyüközkan and Çifçi [90] further published a case study on green supplier evaluation in the automobile industry by proposing a hybrid fuzzy MCDM approach integrating fuzzy DEMATEL, ANP, and TOPSIS. Additionally, Shakourloo et al. [115] studied a supplier selection model in a closed-loop supply chain by combining fuzzy AHP and multi-objective mixed integer linear programming (MOMILP) methods, where they evaluated the proper third-party logistics provider.

\section{Fuzzy TOPSIS}

The Technique for Order Performance by Similarity to Ideal Solution (TOPSIS) was first introduced by Hwang and Yoon [116]. TOPSIS is a tool for selecting optimal solutions from a finite set of alternatives that have the shortest distance from the positive ideal solution and the farthest distance from the negative ideal solution. Here, the positive ideal solution refers to the best performance values and the negative ideal solution refers to the worst performance values $[90,92,110]$. A hybrid fuzzy TOPSIS method evaluates the linguistic data based on the criteria weights for imprecision, subjectivity and vagueness in order for the data to be set into fuzzy numbers $[90,117]$.

The survey identified fuzzy TOPSIS as the second most utilized method within MCDM with 22 out of the 81 papers implementing the methodology. Another interesting finding was that, even though TOPSIS is also effective as a stand-alone methodology, it was mostly combined with AHP and/or ANP. In addition, similar to AHP/ANP, TOPSIS method was often applied to model supplier selection/evaluation problems. For instance, Fallahpour et al. [118] developed a hybrid fuzzy AHP and TOPSIS model for sustainable supplier selection in order to improve the performance of sustainable textile supply chain. Similarly, Prakash and Barua [119] studied a third-party reverse logistics provider selection by employing a hybrid fuzzy AHP and TOPSIS approach. Moreover, Awasthi et al. [92] proposed a fuzzy TOPSIS approach to evaluate the environmental performance of suppliers. In an effort to solve for a green supplier selection problem within an electronics company, Kannan et al. [9] created a framework on the criteria of green supply chain practices using fuzzy TOPSIS. Govindan et al. [120] employed fuzzy TOPSIS to measure sustainability performance based on the triple bottom line approach that consists of four environmental criteria, four economic criteria, and four social criteria for supplier evaluation in a sustainable supply chain.

\section{Fuzzy DEMATEL}

Decision making trial and evaluation laboratory (DEMATEL) was employed by Gabus and Fontela [121] and Gabus and Fontela [122] to build a causal diagram of interdependent complex factors through the formulated relationships between causes and effects in a comprehensive structural model $[113,123]$. In addition to the DEMATEL approach, the hybrid fuzzy DEMATEL addresses the flexibility issue of the fuzziness in order to obtain accurate and reliable results [123,124].

The proposed literature survey found that 13 out of the 97 papers utilized the fuzzy DEMATEL method. Compared to AHP/ANP and TOPSIS methods, DEMATEL is less favorable approach within MCDM techniques. Lin et al. [125] used fuzzy DEMATEL for a green supply chain performance evaluation to improve environmental image and to present a competitive advantage in the automobile manufacturing industry. Lin [123] implemented fuzzy DEMATEL to evaluate the criteria for green supply chain practices that included practices, performance, and external pressures. Wu et al. [124] implemented fuzzy DEMATEL to identify the factors that affected an automobile company's green supply chain performance. In order to assess supply chain risks and uncertainties towards sustainability in an electronics supply chain, Wu et al. [126] employed a novel method based on big data analysis, fuzzy DEMATEL and grey DEMATEL techniques. With regards to this, they identified a set 
of attributes over fuzzy Delphi and grey Delphi techniques and transformed big data to a manageable scale in order to examine their impacts. At the last stage of the model, they implemented fuzzy DEMATEL and grey DEMATEL methods to evaluate the greater risk factors.

\section{Other Fuzzy MCDM Approaches}

VIKOR, first proposed by Opricovic [127], is the method to sequence and select solutions from a set of alternatives with conflicting criteria. This method provides a more comprehensive evaluation in a fuzzy environment where the evaluation is based upon the means of linguistic terms [98,128]. Total number of papers which solely apply VIKOR technique is pretty rare, and this method is majorly integrated with other MCDM techniques as a solution technique. Furthermore, similar to other MCDM methods, a greater number of VIKOR-employed MCDM papers encompasses supplier selection and performance evaluation models. In this regard, Banaeian et al. [129] utilized a hybrid method based on fuzzy TOPSIS, VIKOR, and GRA in order to identify the best supplier within a green agri-food supply chain. Similarly, Prakash and Barua [130] presented a combined model of fuzzy AHP and VIKOR to evaluate and select the best third party logistics provider for an Indian electronics manufacturer. Rostamzadeh et al. [53] applied fuzzy VIKOR in a case study for a Malaysian laptop manufacturer to measure the uncertainty of green supply chain activities, to evaluate green supply chain practices, and to select the best green supply chain practitioner. In addition, Awasthi and Kannan [131] proposed an integrated method based on fuzzy nominal group technique, (NGT)-VIKOR, in order to evaluate and select the best green supplier development programs. Here, fuzzy NGT assigned linguistic ratings to each alternative and criterion, and then fuzzy VIKOR generated the program rankings and introduced the best solutions. Similarly, Akman [98] addressed the evaluation of green supplier development programs through the confirmatory factor analysis and fuzzy c-means-VIKOR in order to determine the environmental performance of suppliers in the automobile industry.

A nonparametric approach called Data Envelopment Analysis (DEA) utilizes linear programming to evaluate the relative efficiencies of a set of decision making units which convert multiple inputs to multiple outputs $[17,132,133]$. Despite the fact that DEA models designate the relative efficiency evaluation of decision making units, solely DEA models can be weak to assess the effectiveness of input data in case of lack of input data noise or insufficient input information. Therefore, incorporating DEA and fuzzy sets would deal with the uncertain information in a proper manner. With regards to further analysis on this method, total number of papers that employ DEA technique sharply increased during the last 5-year period, which shows it is still an emerging modelling technique in the literature. Moreover, it is found that a significant amount of DEA based papers applies artificial neural networks as a solution approach. Azadi et al. [134] utilized a comprehensive fuzzy DEA method to solve the problem of sustainable supplier selection in a resin production company based on environmental, economic, and social dimensions. Mirhedayatian et al. [133] proposed a DEA model that incorporated dual factors, undesirable outputs, and fuzzy data in order to evaluate GSCM performance. Additionally, Fallahpour et al. [135] developed a hybrid DEA-Genetic Programming (GP) approach to evaluate and select the best green supplier, where they referred to adaptive neuro-fuzzy inference system. Similarly, Zhou et al. [136] utilized a type-2 multi-objective DEA model in order to evaluate the most appropriate suppliers within SSCM, where they select the best supplier in case of the balance of economic, environmental, and social dimensions.

Preference Ranking Organization Method for Enrichment Evaluation (PROMETHEE) by Brans et al. [137] is a MCDM technique that allows decision makers to rank a finite number of alternatives in accordance with various criteria to indicate the relative importance of preferred function. It is a simple method compared to other MCDM techniques $[17,111]$, and no study found that uses PROMETHEE as a single approach. This method is not only rarely studied in the literature, but it is supported by an additional MCDM method, specifically AHP/ANP. Tuzkaya et al. [111] utilized a novel fuzzy ANP and fuzzy DEMATEL approach in order to evaluate suppliers' environmental performance in a Turkish white goods case study. Similarly, Tuzkaya [138] developed a hybrid 
fuzzy AHP-DEMATEL method to evaluate and rank the environmental effects of five alternative transportation modes in a specific region among nine criteria.

Measuring Attractiveness by a Categorical Based Evaluation Technique (MACBETH) by Bana e Costa and Vansnick [139] is a ranking method that helps quantify the relative attractiveness of each alternative. This method is similar to AHP even though MACBETH uses an interval scale, while AHP uses a ratio scale $[17,139]$. It can be said that MACBETH is the least favorable MCDM technique in the literature. Dhouib [140] examined an extension of the MACBETH technique in order to assess various reverse logistics options for used automobile tires.

\section{Other Fuzzy-Integrated Approaches}

Few studies involve fuzzy-integrated techniques such as fuzzy rough sets, fuzzy game theory, and fuzzy grey systems. Grey system, a theory derived from grey sets, is a system which copes with both known and unknown information. Grey systems involve five major approaches that include: grey prediction, grey relational analysis, grey decision, grey programming, and grey control [94,141,142]. Total number of fuzzy ECLO articles that incorporate with grey theory increased in the last 5-year period. This hybrid method helps to improve insufficient information, so that overcome uncertainty. Bali et al. [94] studied a green supplier selection problem for an automobile company based on an integrated method of intuitionistic fuzzy set (IFS) and grey relational analysis (GRA). Here, IFS was used to calculate the weights of criteria, where GRA obtained the most appropriate alternative supplier by ranking all alternatives. Moreover, Tseng and Chiu [143] applied a hybrid fuzzy sets and GRA approach to evaluate a Taiwanese printed circuit board manufacturing company's GSCM in order select the suitable green supplier among four suppliers. Wu et al. [144] evaluated the performance of SSCM by combining interval-valued triangular fuzzy numbers with grey relational analysis.

Rough set theory is a mathematical methodology that measures the vagueness, impreciseness, and ambiguity of data. It can be considered as an alternative to fuzzy sets [145]. Kusi-Sarpong et al. [146] evaluated green supply chain practices in the mining industry through a combined rough sets and fuzzy TOPSIS approach. Bai et al. [147] proposed a novel hybrid rough set theoretic and fuzzy clustering means technique for green supplier development to help the organizations manage a thorough and rigorous investment analysis.

Game theory, as defined by Myerson [148], is the study of mathematical models of conflict and cooperation between intelligent rational decision-makers. The theory was first proved by Neumann and Morgenstern [149]. As Zhao et al. [150] also pointed out, game theory is an essential tool in SCM, and its applications in GSCM is still under development. Wei and Zhao [151] combined game theory and fuzzy set theory to solve an optimal pricing decision problem in CLSCM. Additionally, Wei and Zhao [152] implemented a fuzzy theory and game theoretic approach to further focus on the decisions of reverse channel choice in CLSCM. Yang and Xiao [153] utilized Stackelberg scenario analysis with fuzzy degree parameters in order to assess GSCM towards governmental interventions.

\subsection{Industry Categorization}

The majority of the quantitative modeling articles, specifically 241 out of the 425 papers, focused on technology-related industries such as electronics, automotive, energy, and bioenergy followed by consumable goods that included food, apparel and paper. Table 4 depicts the industry distribution across ECLO-focused manuscripts.

Furthermore, Table 5 reflects the distribution of case studies in accordance with industry categorization of 86 out of the 156 fuzzy ECLO manuscripts.

According to Tables 4 and 5, the top three industry categories are electronics, automotive, and energy for both quantitative modelling ECLO papers and fuzzy ECLO papers; hence, based on all the literature, the most favored industry focus is technology. Moreover, the industry categorization of each ECLO paper across each subfield and fuzzy method is depicted in Table A3 (Appendix A). 
Table 4. Industry categorization across ECLO papers (number of studies per industry).

\begin{tabular}{cccccc}
\hline Industry & $\begin{array}{c}\text { No. of } \\
\text { Papers }\end{array}$ & Industry & $\begin{array}{c}\text { No. of } \\
\text { Papers }\end{array}$ & Industry & $\begin{array}{c}\text { No. of } \\
\text { Papers }\end{array}$ \\
\hline Electronics industry & 59 & Recycling industry & 7 & Furniture industry & 3 \\
Automotive industry & 25 & Plastic industry & 7 & Steel industry & 2 \\
Energy industry & 25 & Textile industry & 6 & Aluminum industry & 2 \\
Food industry & 25 & Paper industry & 5 & Packaging industry & 2 \\
Bioenergy industry & 18 & Apparel industry & 4 & Fashion industry & 2 \\
Manufacturing industry & 9 & Healthcare industry & 4 & Pharmaceuticals & 2 \\
Logistics industry & 9 & Mining industry & 4 & Miscellaneous * & 11 \\
Chemicals industry & 7 & Glass industry & 3 & & \\
\hline
\end{tabular}

* Construction, Geyser, Lumber, Resin, Scooter, White goods industry, High-tech industry, Gold industry, Irrigation,

Tank, and Publishing industry.

Table 5. Industry categorization across fuzzy studied ECLO papers (number of studies per industry).

\begin{tabular}{cccc}
\hline Industry & No. of Papers & Industry & No. of Papers \\
\hline Electronics industry & 24 & Bioenergy industry & 4 \\
Automotive industry & 12 & Food industry & 4 \\
Energy industry & 7 & Healthcare industry & 3 \\
Plastic industry & 5 & City logistics & 2 \\
Logistics industry & 4 & Mining industry & 2 \\
Manufacturing industry & 4 & Tire recovery & 2 \\
& & Miscellaneous * & 13
\end{tabular}

* Apparel, Glass, Chemicals, Fashion, Packaging, Paper, Publishing, Resin, Scooter, Steel, Textile, White-goods industry, Pipe.

\section{Summary and Discussion}

This content analysis summarizes and presents some observations in fuzzy intensive environmentally concerned logistics operations (ECLO) articles involving SSCM, GSCM, CLSCM, low-carbon logistics, and logistics operations related waste management. A number of manuscripts were collected and evaluated in order to review the current body of the literature and identify future research directions for ECLO related research.

This paper provides a comprehensive and systematic review, analysis and synthesis of quantitative models in ECLO articles. A special emphasis was then given to peer-reviewed journals, reputed conferences, and book chapters that considered a fuzzy environment. In this respect, a variety of analyses were represented that provide in-depth insight into the existing body of related literature. The main observations are highlighted in the following section.

\section{Current Body of Literature and Future Research Areas}

This work reviewed literature that addresses the environmentally conscious supply chain management problem with a special focus on fuzzy modelling techniques. The analysis included different structural dimensions such as sustainability, quantitative modelling approaches and the fuzzy method used. Five major fields: SSCM, GSCM, CLSCM, low-carbon logistics, and waste management, are used for this review. Regardless of the field, sustainability was the main keyword that was sought out in each article. The results indicate that there has been an increase in research focusing on sustainability in logistics operations.

Three dimensions of sustainability (also known as Triple Bottom Line) include economic, social, and environmental dimensions. The papers considered economic dimension of sustainability constitute the vast majority of the papers, whereas economic dimension was considered as an integral part of environmentally concerned models. It is interesting to note that, despite the fact that total number of papers that discussed the social dimension shows a significant growth in recent years, sustainability dimension is rarely discussed in the surveyed ECLO models indicating the need additional research in 
this area. Further evidence of the lack of research on social dimension is supported by the lack of fuzzy related research such as corporate social responsibility and low-carbon logistics. More specifically, both fuzzy low-carbon logistics and the social dimension of sustainability are identified as two literature gaps. The environmentally focused papers were very predominant among the three dimensions and the findings are compatible with Brandenburg et al. [3], Brandenburg and Rebs [7], and Seuring [27].

In terms of ECLO fields, this paper makes the claim that environmental risk management is mostly disregarded in the literature. In addition, the topic of innovation is a trending topic in the literature, and therefore, should be recognized as an ECLO subfield. It is also important to note that empirical analysis and case study are among the least employed research methodologies, and thus require more attention. Similarly, even though researches employing big data analysis on sustainability in SCM show a significant growth in the literature, only one study found that incorporates big data analysis with fuzzy MCDM technique. With this regard, it is evident that this is an emerging field to be investigated and a significant research opportunity for future researches.

Despite the fact that the majority of the CLSCM and GSCM manuscripts applied one or more quantitative models, less than half of the SSCM papers were analyzed accordingly. Therefore, there is a significant need for ECLO fields based on various quantitative modelling approaches. Regarding the model-based techniques, MCDM methods are the primary approach in all of the ECLO related articles where AHP/ANP combination is the most frequently used tool. Simulation related techniques were the least frequently applied tools. According to the fuzzy approach, $36 \%$ of the overall ECLO related papers were investigated in a fuzzy environment where the greater proportion of these papers constitute the integration with MCDM. When the distribution of the fuzzy involved papers across ECLO fields, the findings identified that the majority of the papers consist of GSCM, followed by CLSCM, SSCM, low-carbon logistics, and waste management. Since the fields of low-carbon logistics and logistics-related waste management constitute the minority of overall papers, SSCM would be the least examined problem in a fuzzy environment. It is also important to note that majority of the supplier selection/evaluation and performance assessment problems are modeled using fuzzy MCDM techniques with fuzzy AHP/ANP being the most popular approach.

In addition to fuzzy models, it is important to highlight the importance of related big data and data analytics research where large volumes of unstructured data are collected and analyzed for better predictive modeling.

\section{Conclusions}

In this paper, a comprehensive literature review based on the use of environmentally concerned logistics operations (ECLO) in fuzzy environment was performed. Here, ECLO was identified as the governing umbrella that embody sustainable supply chain management, green supply chain management, closed-loop supply chain management, low-carbon logistics, and waste management in logistics operations. Over 800 articles were reviewed that cover approximately two decades of research. Further analysis was conducted to examine in-depth analysis of the body of related literature from various perspectives. The content analysis was implemented in consecutive stages, where the papers were classified according to several structural dimensions such as sustainability, research methodologies, quantitative modelling techniques, and intended fuzzy methods. As a result, 156 papers which were categorized as fuzzy-related ECLO studies that were detailed followed by a comprehensive overview of the body of ECLO literature. Accordingly, existing fuzzy ECLO literature was discussed thoroughly, and was classified according to each fuzzy method used in each of the ECLO fields and subfields. The results clearly show that the fuzzy multi-criteria decision making technique is a frequently used hybrid method; whereas, the papers that apply solely fuzzy set theory in ECLO models constitute the minority of related literature. Moreover, fuzzy-related SSCM papers comprise of smaller number of publications compared to other ECLO fields. The findings indicate the need for additional research in the field of environmentally concerned logistics, mainly in SSCM, where single fuzzy set theory models are applied. 
Fuzzy set theory allows the transformation of linguistic expressions into numerical values. Therefore, the managerial implications of this research include utilization of fuzzy set theory in decision maker-centered systems. Transforming the preferences of decision makers into a format suitable for quantitative decision making would enable the system designers with the ability to incorporate expert judgement into the model environment. By benefiting from decision maker's experiences, businesses can create decision maker-centered systems where both collected data and subjective judgement are taken into account. These systems are especially more beneficial when used for data-rich, information-poor environments where additional input from business partners is important. Furthermore, environmentally conscious supply chain and logistics systems are known to embody several parties making timely and accurate information sharing a challenge. Introduction of fuzziness into such systems would provide related platforms with the much needed flexibility in decision making.

Acknowledgments: The authors would like to thank Camy Deck for proof reading the article that greatly improved the manuscript.

Author Contributions: All authors have made contributions to the work reported in the manuscript. The authors are listed in order of their contributions.

Conflicts of Interest: The authors declare no conflict of interest.

\section{Appendix A}

Table A1. The distribution of the papers published in other journals.

\begin{tabular}{|c|c|}
\hline Journals & No. of Articles \\
\hline Applied Mathematical Modeling & 13 \\
\hline Computers and Chemical Engineering & 12 \\
\hline Procedia-Social and Behavioral Sciences & 12 \\
\hline International Journal of Physical Distribution and Logistics Management & 11 \\
\hline Journal of Business Ethics, Computers and Operations Research & 10 Each \\
\hline Journal of Purchasing and Supply Management, Procedia CIRP & 9 Each \\
\hline Journal of Supply Chain Management, Journal of Manufacturing Systems & 7 Each \\
\hline $\begin{array}{l}\text { Business Strategy and the Environment, International Journal of Environmental Science and Technology, Production Planning and Control: } \\
\text { The Management of Operations, Transportation Research Part D: Transport and Environment }\end{array}$ & 6 Each \\
\hline $\begin{array}{l}\text { Applied Soft Computing, International Journal of Operations and Production Management, Journal of Environmental Management, Journal of } \\
\text { Operations Management, The International Journal of Advanced Manufacturing Technology }\end{array}$ & 5 Each \\
\hline $\begin{array}{l}\text { Annals of Operations Research, Applied Energy, Benchmarking: An International Journal, Corporate Social Responsibility and Environmental } \\
\text { Management, Resources Policy, Supply Chain Management }\end{array}$ & 4 Each \\
\hline $\begin{array}{l}\text { Ecological Economics, Energy, Journal of Manufacturing Technology Management, Journal of Transport Geography, The International Journal of } \\
\text { Logistics Management, Fuzzy Sets and Systems, IFAC, Industrial Marketing Management, International Strategic Management Review, Sustainable } \\
\text { Production and Consumption, Waste Management }\end{array}$ & 3 Each \\
\hline $\begin{array}{l}\text { AIChE Journal, Biomass and Bioenergy, Bioresource Technology, Business Process Management Journal, Decision Support Systems, European Journal of } \\
\text { Purchasing and Supply Management, Ecological Indicators, Food Policy, Global Journal of Flexible Systems Management, Industrial Management and } \\
\text { Data Systems, Industrial Marketing Management, International Journal of Hydrogen Energy, International Journal of Logistics Systems and } \\
\text { Management, International Journal of Productivity and Performance Management, International Journal of Sustainable Engineering, Journal of } \\
\text { Industrial Engineering and Management, Journal of the Operational Research Society, Logistics Research, Management Research Review, Mathematical } \\
\text { Problems in Engineering, Operations and Supply Chain Management, Procedia Engineering, Grey Systems: Theory and Application, Industrial and } \\
\text { Engineering Chemistry Research }\end{array}$ & 2 Each \\
\hline 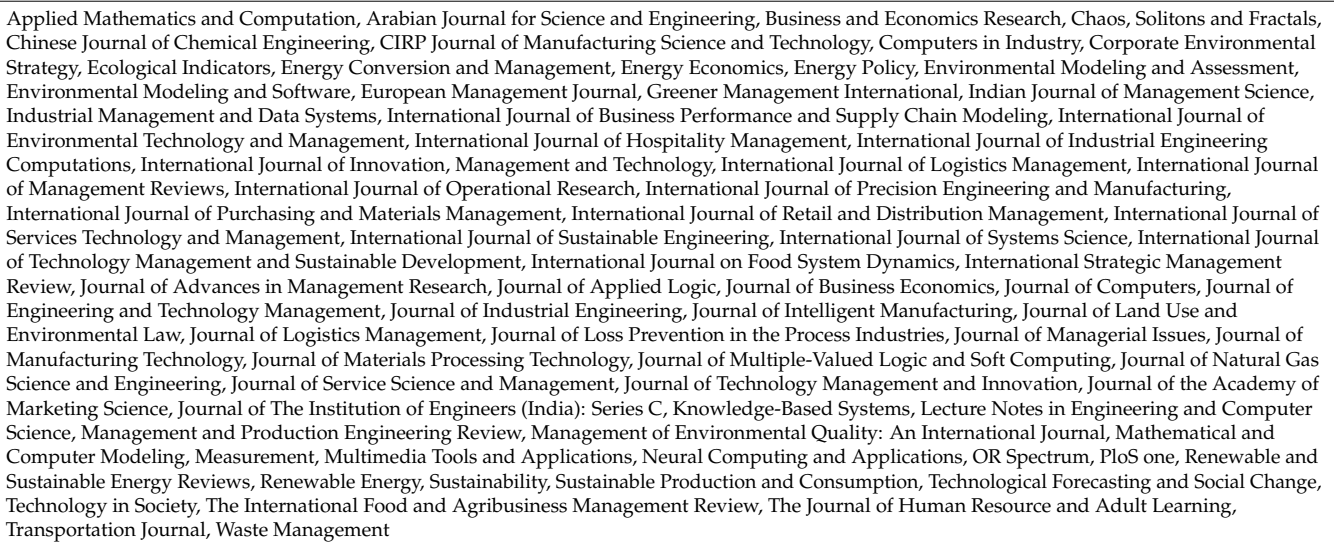 & 1 Each \\
\hline Proceedings & 31 \\
\hline Books & 4 \\
\hline
\end{tabular}


Table A2. Assignments of the papers according to the related modeling techniques ${ }^{(a)}$.

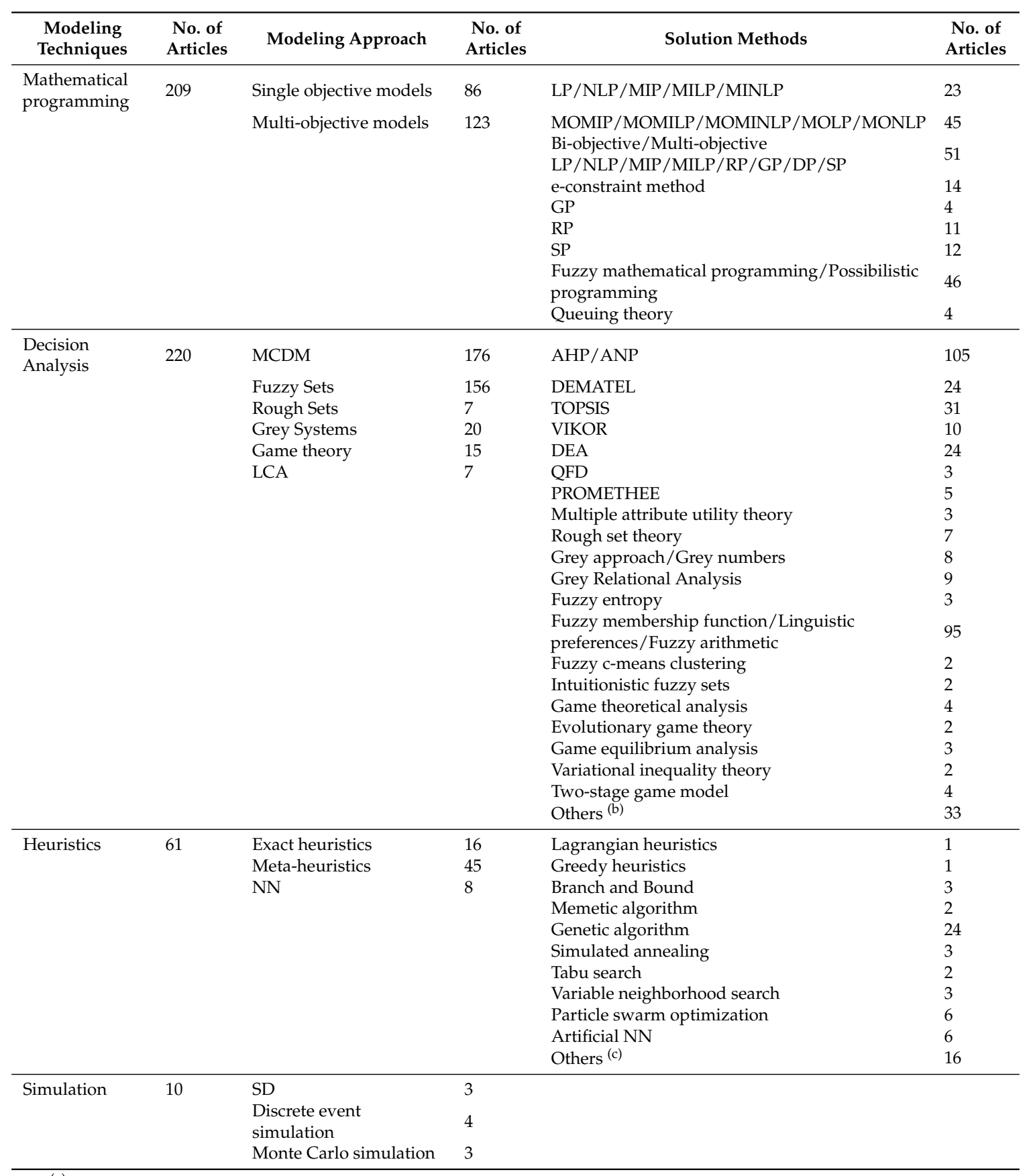

(a) The inequality between the total number of the papers assigned to each technique and the total number of the papers assigned to each approach is caused by the hybrid studies combining two or more approaches; ${ }^{(b)}$ ELECTRE, MACBETH, Grey Correlation Analysis, Grey entropy, Fuzzy axiomatic design, Fuzzy logic controller, Incomplete preference relations, Interpretive ranking process, Fuzzy integrated enhanced Russell measure, Dual-role factors, Online analytical processing data (OLAP) cube model, Weight analysis, Graph theoretic and matrix approach, Fault-tree analysis, Adaptive neuro-fuzzy inference system, Fuzzy nominal group technique, Governing network equilibrium model, Fuzzy inference system, Fuzzy extent analysis, Input-output analysis, Stackelberg scenario analysis, Best-Worst Method, Interval-valued fuzzy hesitant set, Fuzzy ranking method; (c) Two-phased heuristics, Adapted imperialist competitive algorithm, Nested integrated cross-entropy, Adaptive neuro-fuzzy inference system, Clarke-Wright algorithm, Ant colony optimization, Nearest neighborhood search, Artificial bee colony, Sample average approximation, Decomposition heuristics, Differential evolution algorithm, Continuous approximation. 
Table A3. Classification of each ECLO topics across the subfields and fuzzy-related approaches (a).

\begin{tabular}{|c|c|c|c|c|c|c|c|}
\hline $\begin{array}{l}\text { ECLO } \\
\text { Field }\end{array}$ & $\begin{array}{l}\text { No. of } \\
\text { Articles }\end{array}$ & Subfields & $\begin{array}{l}\text { No. of } \\
\text { Articles }\end{array}$ & $\begin{array}{c}\text { Fuzzy-Related } \\
\text { Approach }\end{array}$ & $\begin{array}{l}\text { No. of } \\
\text { Articles }\end{array}$ & Industry & Articles \\
\hline \multirow[t]{31}{*}{ SSCM } & \multirow[t]{31}{*}{29} & \multirow[t]{6}{*}{ Supplier Selection/Evaluation } & \multirow[t]{6}{*}{12} & Fuzzy sets & 5 & Manufacturing; Healthcare; Textile & {$[76,85,87,118,136]$} \\
\hline & & & & Fuzzy AHP & 5 & Automotive; Apparel; Textile & {$[89,118,154-156]$} \\
\hline & & & & Fuzzy ANP & 1 & White goods & [88] \\
\hline & & & & Fuzzy DEA & 2 & Resin & {$[134,136]$} \\
\hline & & & & Fuzzy TOPSIS & 3 & Energy; Textile & {$[118,155,157]$} \\
\hline & & & & Fuzzy MOLP & 3 & Apparel & {$[89,154,158]$} \\
\hline & & \multirow[t]{4}{*}{ Network Design } & \multirow[t]{4}{*}{4} & Fuzzy DEA & 1 & & [159] \\
\hline & & & & Fuzzy GP & 1 & Bioenergy; Energy & {$[158,160]$} \\
\hline & & & & Fuzzy MILP & 1 & Energy & {$[160]$} \\
\hline & & & & Fuzzy MOLP & 2 & Biofuel & {$[161,162]$} \\
\hline & & \multirow[t]{6}{*}{ Performance Assessment } & \multirow[t]{6}{*}{5} & Fuzzy sets & 1 & & [97] \\
\hline & & & & Fuzzy AHP & 1 & Apparel & [154] \\
\hline & & & & Fuzzy ANP & 1 & Electronics & \\
\hline & & & & Fuzzy DEMATEL & 1 & & [163] \\
\hline & & & & Fuzzy MOLP & 1 & Apparel & {$[154]$} \\
\hline & & & & Fuzzy GRA & 1 & & {$[144]$} \\
\hline & & \multirow[t]{6}{*}{ Carbon Emissions } & \multirow[t]{6}{*}{4} & Fuzzy AHP & 1 & & [89] \\
\hline & & & & Fuzzy DEA & 1 & & [159] \\
\hline & & & & Fuzzy LP & 1 & & [89] \\
\hline & & & & Fuzzy MOLP & 1 & & [161] \\
\hline & & & & Fuzzy MOMILP & 1 & Electronics & {$[164]$} \\
\hline & & & & Fuzzy SP & 1 & Electronics & [164] \\
\hline & & \multirow[t]{3}{*}{ Sustainable Development } & \multirow[t]{3}{*}{4} & Fuzzy Sets & 2 & Logistics; Plastic & {$[165,166]$} \\
\hline & & & & Fuzzy AHP & 2 & Energy; Automotive & {$[167,168]$} \\
\hline & & & & Fuzzy MOLP & 1 & Biofuel & [162] \\
\hline & & Environmental Management & 1 & Fuzzy TOPSIS & 1 & & [120] \\
\hline & & \multirow[t]{2}{*}{ Order Allocation } & \multirow[t]{2}{*}{1} & Fuzzy AHP & 1 & Automotive & [169] \\
\hline & & & & Fuzzy MOLP & 1 & Automotive & [169] \\
\hline & & \multirow[t]{3}{*}{ Risk Management } & \multirow[t]{3}{*}{3} & Fuzzy DEMATEL & 1 & Electronics & [126] \\
\hline & & & & Fuzzy LP & 1 & & [170] \\
\hline & & & & Fuzzy MOLP & 1 & Biofuel & {$[162]$} \\
\hline \multirow[t]{4}{*}{ GSCM } & \multirow[t]{4}{*}{74} & \multirow[t]{4}{*}{ Supplier Selection/Evaluation } & \multirow[t]{4}{*}{32} & Fuzzy sets & 6 & Plastic & {$[86,99,102,144,170-172]$} \\
\hline & & & & Fuzzy AHP & 8 & Electronics & {$[91,93,104,173-177]$} \\
\hline & & & & Fuzzy ANP & 5 & Automotive & {$[90,111,132,178,179]$} \\
\hline & & & & Fuzzy DEA & 1 & Textile & [135] \\
\hline
\end{tabular}


Table A3. Cont.

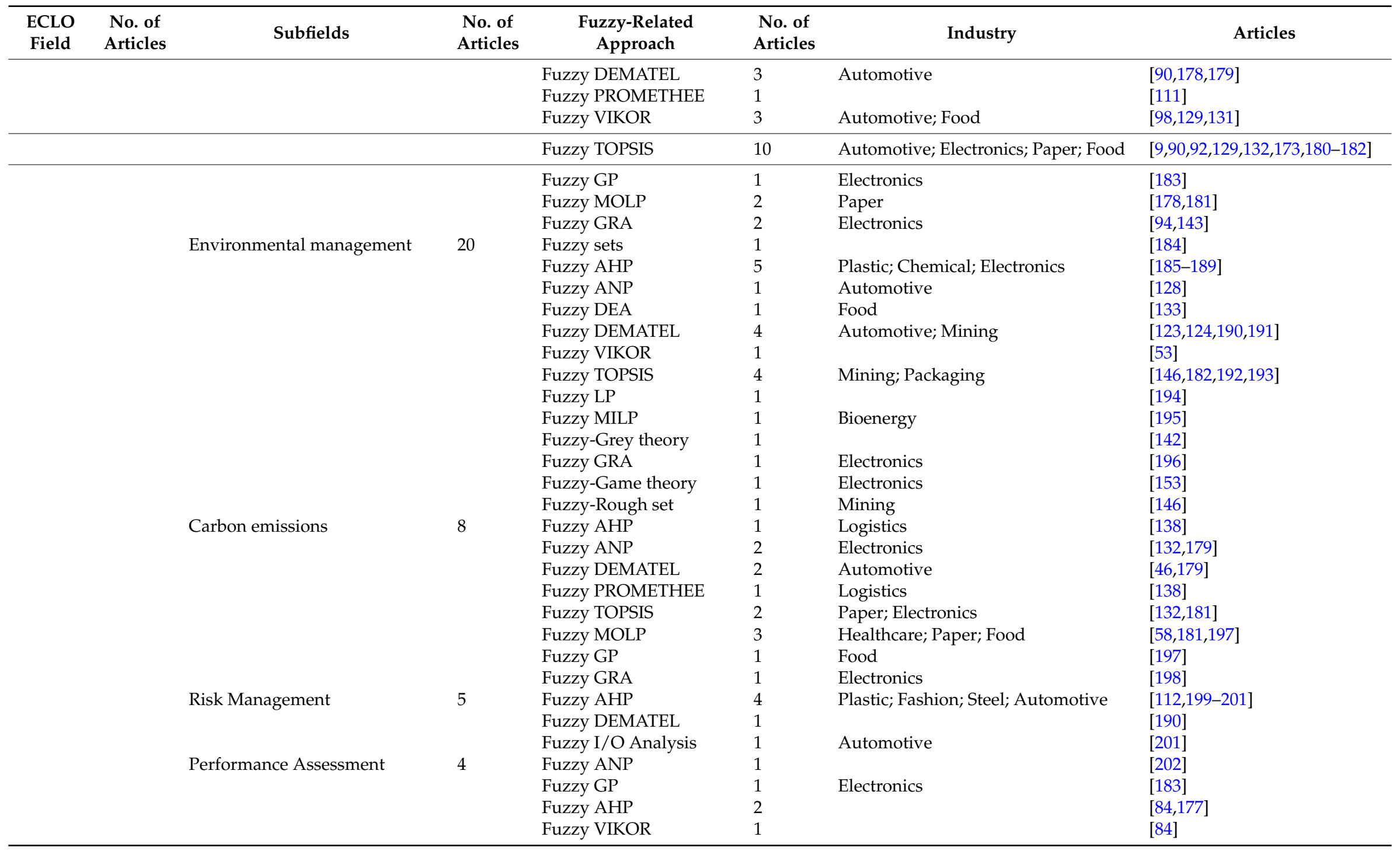


Table A3. Cont.

\begin{tabular}{|c|c|c|c|c|c|c|c|}
\hline $\begin{array}{l}\text { ECLO } \\
\text { Field }\end{array}$ & $\begin{array}{c}\text { No. of } \\
\text { Articles }\end{array}$ & Subfields & $\begin{array}{c}\text { No. of } \\
\text { Articles }\end{array}$ & $\begin{array}{c}\text { Fuzzy-Related } \\
\text { Approach }\end{array}$ & $\begin{array}{c}\text { No. of } \\
\text { Articles }\end{array}$ & Industry & Articles \\
\hline & & Sustainable Development & 4 & Fuzzy AHP & 3 & Plastic; Publishing & {$[166,203,204]$} \\
\hline & & & & Fuzzy TOPSIS & 1 & Plastic & [166] \\
\hline & & & & Fuzzy GRA & 1 & Electronics & [201] \\
\hline & & Corporate social responsibility & 3 & Fuzzy AHP & 2 & Electronics & {$[91,175]$} \\
\hline & & & & Fuzzy GRA & 1 & Electronics & [198] \\
\hline & & Life Cycle Assessment & 3 & Fuzzy MOLP & 2 & Healthcare & {$[205,206]$} \\
\hline & & & & Fuzzy AHP & 1 & Automotive & [201] \\
\hline & & & & Fuzzy I/O Analysis & 1 & Automotive & [201] \\
\hline & & Network design & 3 & Fuzzy MOLP & 3 & Healthcare; Food & {$[197,205,206]$} \\
\hline & & & & Fuzzy GP & 1 & Food & [197] \\
\hline & & Reverse Logistics & 1 & Fuzzy sets & 1 & Logistics & [207] \\
\hline & & Others $^{(b)}$ & 9 & Fuzzy sets & 1 & Logistics & [208] \\
\hline & & & & Fuzzy AHP & 3 & Logistics; Fashion & {$[104,112,138]$} \\
\hline & & & & Fuzzy ANP & 2 & Electronics & {$[209,210]$} \\
\hline & & & & Fuzzy DEMATEL & 3 & Automotive & {$[46,125,210]$} \\
\hline & & & & Fuzzy PROMETHEE & 1 & Logistics & [138] \\
\hline & & & & Fuzzy TOPSIS & 1 & & [210] \\
\hline & & & & Fuzzy GP & 1 & Electronics & [183] \\
\hline & & & & Fuzzy-Rough set & 1 & & [147] \\
\hline \multirow[t]{16}{*}{ CLSCM } & 45 & Network Design & 15 & Fuzzy AHP & 1 & Scooter & [211] \\
\hline & & & & Fuzzy ANP & 1 & & [212] \\
\hline & & & & Fuzzy LP & 1 & & [213] \\
\hline & & & & Fuzzy MIP & 1 & Recycling & [214] \\
\hline & & & & Fuzzy MILP & 3 & & [215-217] \\
\hline & & & & Fuzzy MOLP & 4 & Healthcare & {$[106,218-220]$} \\
\hline & & & & Fuzzy bi-objective MIP & 1 & Food & [221] \\
\hline & & & & Fuzzy GP & 2 & Recycling & {$[222,223]$} \\
\hline & & & & Fuzzy RP & 2 & Electronics & {$[224,225]$} \\
\hline & & Reverse Logistics & 21 & Fuzzy sets & 2 & Glass & {$[99,107]$} \\
\hline & & & & Fuzzy AHP & 5 & Electronics; Pipe & {$[115,118,130,226,227]$} \\
\hline & & & & Fuzzy DEMATEL & & Manufacturing & {$[228]$} \\
\hline & & & & Fuzzy MACBETH & 1 & Recycling & [140] \\
\hline & & & & Fuzzy TOPSIS & 2 & & {$[119,130,229]$} \\
\hline & & & & Fuzzy VIKOR & 1 & & [130] \\
\hline & & & & Fuzzy MIP & 6 & Automotive; Electronics & {$[216,217,230-233]$} \\
\hline
\end{tabular}


Table A3. Cont.

\begin{tabular}{|c|c|c|c|c|c|c|}
\hline $\begin{array}{c}\text { No. of } \\
\text { Articles }\end{array}$ & Subfields & $\begin{array}{c}\text { No. of } \\
\text { Articles }\end{array}$ & $\begin{array}{c}\text { Fuzzy-Related } \\
\text { Approach }\end{array}$ & $\begin{array}{c}\text { No. of } \\
\text { Articles }\end{array}$ & Industry & Articles \\
\hline & \multirow{9}{*}{ Third party providers } & \multirow{9}{*}{8} & Fuzzy MOLP & 2 & \multirow[t]{5}{*}{ Healthcare } & {$[220,234]$} \\
\hline & & & Fuzzy MOMILP & 1 & & [115] \\
\hline & & & Fuzzy RP & 1 & & [225] \\
\hline & & & Fuzzy-Game theory & 1 & & [152] \\
\hline & & & Fuzzy sets & 1 & & [101] \\
\hline & & & Fuzzy AHP & 4 & Electronics; Pipe & {$[114,115,119,228]$} \\
\hline & & & Fuzzy TOPSIS & 2 & Recycling & {$[117,235]$} \\
\hline & & & Fuzzy VIKOR & 1 & Electronics & [130] \\
\hline & & & Fuzzy MOMILP & 1 & & [115] \\
\hline & \multirow[t]{2}{*}{ Order allocation } & \multirow[t]{2}{*}{2} & Fuzzy sets & 1 & & [107] \\
\hline & & & Fuzzy GP & 1 & Manufacturing & [82] \\
\hline & Performance evaluation & 2 & Fuzzy sets & 2 & Automotive & {$[96,236]$} \\
\hline & \multirow[t]{4}{*}{ Supplier Selection/Evaluation } & \multirow[t]{4}{*}{3} & Fuzzy LP & 1 & & [237] \\
\hline & & & Fuzzy AHP & 1 & & [115] \\
\hline & & & Fuzzy MOMILP & & & [115] \\
\hline & & & Fuzzy GP & 1 & Manufacturing & [82] \\
\hline & \multirow[t]{2}{*}{ Carbon emissions } & \multirow[t]{2}{*}{2} & Fuzzy RP & 1 & Electronics & [224] \\
\hline & & & Fuzzy MILP & & Electronics & [233] \\
\hline & Facility location & 1 & Fuzzy MINLP & 1 & & [238] \\
\hline & Life Cycle Assessment & 1 & Fuzzy GP & 1 & Recycling & [105] \\
\hline & \multirow[t]{2}{*}{ Sustainable Development } & \multirow[t]{2}{*}{2} & Fuzzy AHP & 2 & Electronics & {$[211,239]$} \\
\hline & & & Fuzzy MIP & 1 & Automotive & [232] \\
\hline \multirow{2}{*}{$\begin{array}{l}\text { Low-Carbon } \\
\text { Logistics }\end{array}$} & \multirow[t]{2}{*}{ Sustainable development } & \multirow[t]{2}{*}{2} & Fuzzy LP & 1 & Energy & [240] \\
\hline & & & Fuzzy DEA & 1 & & [241] \\
\hline \multirow[t]{3}{*}{$\begin{array}{l}\text { Waste } \\
\text { Management }\end{array}$} & \multirow{3}{*}{$\begin{array}{l}\text { Hazardous Substance } \\
\text { Management } \\
\text { Risk Management }\end{array}$} & \multirow{3}{*}{$\begin{array}{l}2 \\
1\end{array}$} & Fuzzy sets & 2 & Manufacturing; Logistics & {$[207,242]$} \\
\hline & & & Fuzzy AHP & 1 & Automotive & [202] \\
\hline & & & Fuzzy I/O Analysis & 1 & Automotive & [202] \\
\hline
\end{tabular}

(a) The inequality between the total number of the papers assigned to each ECLO field and subfield, and the total number of the papers assigned to each method is caused by the hybrid studies combining two or more approaches; ${ }^{(b)}$ Investment Management, Purchasing, Vehicle Routing, Green initiatives, Order Allocation, and Cost management. 
Table A4. Classification of each ECLO topics across the top subfields and MCDM approaches (a).

\begin{tabular}{|c|c|c|c|c|c|}
\hline $\begin{array}{l}\text { ECLO } \\
\text { Field }\end{array}$ & $\begin{array}{c}\text { No. of } \\
\text { Articles }\end{array}$ & Subfields & $\begin{array}{l}\text { No. of } \\
\text { Articles }\end{array}$ & MCDM Approach & $\begin{array}{c}\text { No. of } \\
\text { Articles }\end{array}$ \\
\hline \multirow[t]{23}{*}{ SSCM } & \multirow[t]{23}{*}{43} & \multirow[t]{6}{*}{ Sustainable development } & \multirow[t]{6}{*}{16} & AHP / ANP & 8 \\
\hline & & & & DEA & 3 \\
\hline & & & & DEMATEL & 1 \\
\hline & & & & TOPSIS & 1 \\
\hline & & & & Hybrid (AHP and TOPSIS) & 2 \\
\hline & & & & Best-Worst Analysis & 1 \\
\hline & & \multirow[t]{4}{*}{ Supplier selection/evaluation } & \multirow[t]{4}{*}{11} & AHP/ANP & 5 \\
\hline & & & & DEA & 2 \\
\hline & & & & DEMATEL & 2 \\
\hline & & & & TOPSIS & 2 \\
\hline & & \multirow[t]{3}{*}{ Carbon emissions } & \multirow[t]{3}{*}{6} & AHP/ANP & 2 \\
\hline & & & & DEA & 3 \\
\hline & & & & Hybrid (AHP and TOPSIS) & 1 \\
\hline & & \multirow[t]{5}{*}{ Performance assessment } & \multirow[t]{5}{*}{6} & AHP/ANP & 1 \\
\hline & & & & DEA & 2 \\
\hline & & & & DEMATEL & 1 \\
\hline & & & & MAUT & 1 \\
\hline & & & & $\mathrm{AHP} / \mathrm{ANP}$ & 1 \\
\hline & & \multirow[t]{2}{*}{ Network design } & \multirow[t]{2}{*}{4} & $\mathrm{AHP} / \mathrm{ANP}$ & 1 \\
\hline & & & & DEA & 3 \\
\hline & & Environmental management & 1 & TOPSIS & 1 \\
\hline & & Order allocation & 1 & $\mathrm{AHP} / \mathrm{ANP}$ & 1 \\
\hline & & Risk Management & 2 & DEMATEL & 2 \\
\hline \multirow[t]{43}{*}{ GSCM } & 104 & Supplier selection/evaluation & 50 & $\mathrm{AHP} / \mathrm{ANP}$ & 19 \\
\hline & & & & DEA & 5 \\
\hline & & & & DEMATEL & 3 \\
\hline & & & & PROMETHEE & 1 \\
\hline & & & & TOPSIS & 8 \\
\hline & & & & VIKOR & 3 \\
\hline & & & & Hybrid (AHP/ANP and DEA) & 3 \\
\hline & & & & Hybrid (ANP and PROMETHEE) & 1 \\
\hline & & & & Hybrid (ANP and DEMATEL) & 2 \\
\hline & & & & Hybrid (ANP and DEMATEL and TOPSIS) & 1 \\
\hline & & & & Hybrid (AHP/ANP and TOPSIS) & 2 \\
\hline & & & & Hybrid (ELECTRE and VIKOR) & 1 \\
\hline & & & & Hybrid (ANP and DEMATEL and VIKOR) & 1 \\
\hline & & & & Hybrid(ANP and DEMATEL and MAUT) & 1 \\
\hline & & & & Hybrid(TOPSIS and VIKOR) & 1 \\
\hline & & Environmental management & 25 & $\mathrm{AHP} / \mathrm{ANP}$ & 11 \\
\hline & & & & DEA & 1 \\
\hline & & & & DEMATEL & 5 \\
\hline & & & & PROMETHEE & 1 \\
\hline & & & & TOPSIS & 4 \\
\hline & & & & VIKOR & 1 \\
\hline & & & & Hybrid (AHP and VIKOR) & 1 \\
\hline & & & & Hybrid (ANP and DEMATEL) & 1 \\
\hline & & Carbon emissions & 13 & $\mathrm{AHP} / \mathrm{ANP}$ & 2 \\
\hline & & & & DEA & 3 \\
\hline & & & & DEMATEL & 2 \\
\hline & & & & TOPSIS & 1 \\
\hline & & & & Hybrid (AHP and PROMETHEE) & 1 \\
\hline & & & & Hybrid (ANP and DEMATEL) & 1 \\
\hline & & & & Hybrid (AHP/ANP and DEA) & 1 \\
\hline & & & & Hybrid (AHP and PROMETHEE) & 1 \\
\hline & & & & Hybrid (ANP and TOPSIS) & 1 \\
\hline & & Performance assessment & 6 & $\mathrm{AHP} / \mathrm{ANP}$ & 2 \\
\hline & & & & DEMATEL & 1 \\
\hline & & & & VIKOR & 1 \\
\hline & & & & Hybrid(AHP and TOPSIS) & 1 \\
\hline & & & & Hybrid(AHP and VIKOR) & 1 \\
\hline & & Sustainable development & 4 & $\mathrm{AHP} / \mathrm{ANP}$ & 3 \\
\hline & & & & Hybrid (ANP and TOPSIS) & 1 \\
\hline & & Corporate social responsibility & 6 & $\mathrm{AHP} / \mathrm{ANP}$ & 2 \\
\hline & & & & DEMATEL & 1 \\
\hline & & & & PROMETHEE & 1 \\
\hline & & & & Hybrid(ANP and DEA) & 1 \\
\hline
\end{tabular}


Table A4. Cont.

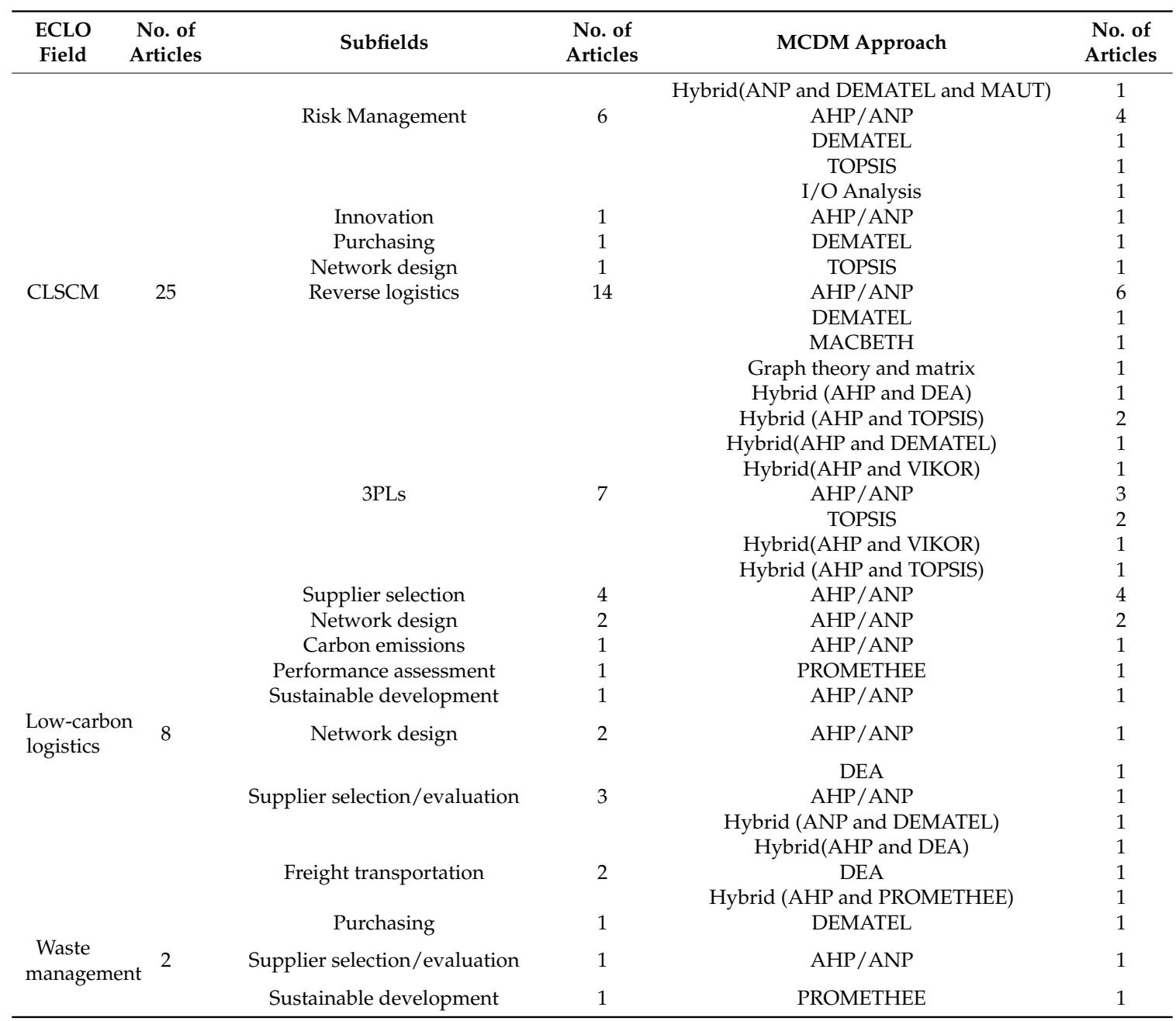

(a) The inequality between the total number of the papers assigned to each ECLO field and subfield, and the total number of the papers assigned to each method is caused by the hybrid studies combining two or more approaches.

\section{References}

1. Ilgin, M.A.; Gupta, S.M. Environmentally conscious manufacturing and product recovery (ECMPRO): A review of the state of the art. J. Environ. Manag. 2010, 91, 563-591. [CrossRef] [PubMed]

2. Min, H.; Kim, I. Green supply chain research: Past, present, and future. Logist. Res. 2012, 4, 39-47. [CrossRef]

3. Brandenburg, M.; Govindan, K.; Sarkis, J.; Seuring, S. Quantitative models for sustainable supply chain management: Developments and directions. Eur. J. Oper. Res. 2014, 233, 299-312. [CrossRef]

4. Lambert, D.M.; Cooper, M.C.; Pagh, J.D. Supply chain management: Implementation issues and research opportunities. Int. J. Logist. Manag. 1998, 9, 1. [CrossRef]

5. Linton, J.D.; Klassen, R.; Jayaraman, V. Sustainable supply chains: An introduction. J. Oper. Manag. 2007, 25, 1075-1082. [CrossRef]

6. Diabat, A.; Kannan, D.; Mathiyazhagan, K. Analysis of enablers for implementation of sustainable supply chain management-A textile case. J. Clean. Prod. 2014, 83, 391-403. [CrossRef]

7. Brandenburg, M.; Rebs, T. Sustainable supply chain management: A modeling perspective. Ann. Oper. Res. 2015, 229, 213-252. [CrossRef]

8. Elkington, J. Cannibals with Forks: The Triple Bottom Line of the 21st Century; New Society: Stoney Creek, CT, USA, 1998.

9. Kannan, D.; Jabbour, A.B.L.d.S.; Jabbour, C.J.C. Selecting green suppliers based on GSCM practices: Using fuzzy TOPSIS applied to a Brazilian electronics company. Eur. J. Oper. Res. 2014, 233, 432-447. [CrossRef] 
10. Seuring, S.; Müller, M. From a literature review to a conceptual framework for sustainable supply chain management. J. Clean. Prod. 2008, 16, 1699-1710. [CrossRef]

11. Ahi, P.; Searcy, C. A comparative literature analysis of definitions for green and sustainable supply chain management. J. Clean. Prod. 2013, 52, 329-341. [CrossRef]

12. Bai, C.; Sarkis, J. Green supplier development: Analytical evaluation using rough set theory. J. Clean. Prod. 2010, 18, 1200-1210. [CrossRef]

13. Govindan, K.; Cheng, T.C.E. Environmental supply chain management. Resour. Conserv. Recycl. 2011, 55, 557-558. [CrossRef]

14. Jabbour, A.B.L.d.S.; Frascareli, F.C.d.O.; Jabbour, C.J.C. Green supply chain management and firms' performance: Understanding potential relationships and the role of green sourcing and some other green practices. Resour. Conserv. Recycl. 2015, 104, 366-374. [CrossRef]

15. Shang, K.-C.; Lu, C.-S.; Li, S. A taxonomy of green supply chain management capability among electronics-related manufacturing firms in Taiwan. J. Environ. Manag. 2010, 91, 1218-1226. [CrossRef] [PubMed]

16. Sarkis, J. A boundaries and flows perspective of green supply chain management. Supply Chain Manag. 2012, 17, 202-216. [CrossRef]

17. Ilgin, M.A.; Gupta, S.M.; Battaïa, O. Use of MCDM techniques in environmentally conscious manufacturing and product recovery: State of the art. J. Manuf. Syst. 2015, 37, 746-758. [CrossRef]

18. Sasikumar, P.; Kannan, G. Issues in reverse supply chains, part I: End-of-life product recovery and inventory management-An overview. Int. J. Sustain. Eng. 2008, 1, 154-172. [CrossRef]

19. Sbihi, A.; Eglese, R.W. Combinatorial optimization and Green Logistics. Ann. Oper. Res. 2010, 175, $159-175$. [CrossRef]

20. Srivastava, S.K. Green supply-chain management: A state-of-the-art literature review. Int. J. Manag. Rev. 2007, 9, 53-80. [CrossRef]

21. Sarkis, J.; Zhu, Q.; Lai, K.-H. An organizational theoretic review of green supply chain management literature. Int. J. Prod. Econ. 2011, 130, 1-15. [CrossRef]

22. Igarashi, M.; de Boer, L.; Fet, A.M. What is required for greener supplier selection? A literature review and conceptual model development. J. Purch. Supply Manag. 2013, 19, 247-263. [CrossRef]

23. Govindan, K.; Rajendran, S.; Sarkis, J.; Murugesan, P. Multi criteria decision making approaches for green supplier evaluation and selection: A literature review. J. Clean. Prod. 2015, 98, 66-83. [CrossRef]

24. Gold, S.; Seuring, S.; Beske, P. Sustainable supply chain management and inter-organizational resources: A literature review. Corp. Soc. Responsib. Environ. Manag. 2010, 17, 230-245. [CrossRef]

25. Hassini, E.; Surti, C.; Searcy, C. A literature review and a case study of sustainable supply chains with a focus on metrics. Int. J. Prod. Econ. 2012, 140, 69-82. [CrossRef]

26. Gao, D.; Xu, Z.; Ruan, Y.Z.; Lu, H. From a systematic literature review to integrated definition for sustainable supply chain innovation (SSCI). J. Clean. Prod. 2017, 142, 1518-1538. [CrossRef]

27. Seuring, S. A review of modeling approaches for sustainable supply chain management. Decis. Support Syst. 2013, 54, 1513-1520. [CrossRef]

28. Fink, A. Conducting Research Literature Reviews: From Paper to the Internet, 4th ed.; Sage: Thousand Oaks, CA, USA, 1998.

29. Tranfield, D.; Denyer, D.; Smart, P. Towards a Methodology for Developing Evidence-Informed Management Knowledge by Means of Systematic Review. Br. J. Manag. 2003, 14, 207-222. [CrossRef]

30. Morali, O.; Searcy, C. A Review of Sustainable Supply Chain Management Practices in Canada. J. Bus. Ethics 2013, 117, 635-658. [CrossRef]

31. Carter, C.R.; Easton, P.L. Sustainable supply chain management: Evolution and future directions. Int. J. Phys. Distrib. Logist. Manag. 2011, 41, 46-62. [CrossRef]

32. Booth, A.; Sutton, A.; Papaioannou, D. Systematic Approaches to a Successful Literature Review; Sage: Thousand Oaks, CA, USA, 2016.

33. Hsieh, H.-F.; Shannon, S.E. Three Approaches to Qualitative Content Analysis. Qual. Health Res. 2005, 15, 1277-1288. [CrossRef] [PubMed]

34. Cronin, P.; Ryan, F.; Coughlan, M. Undertaking a literature review: A step-by-step approach. Br. J. Nurs. 2008, 17, 38. [CrossRef] [PubMed]

35. Mayring, P. Qualitative Inhaltsanalyse (Qualitative Content aNalysis), 10th ed.; Beltz: Weinheim, Germany, 2008. 
36. Mayring, P. Qualitative Sozialforschung (Qualitative Social Research), 5th ed.; Beltz: Weinheim, Germany, 2002.

37. Seuring, S.; Gold, S. Conducting content-analysis based literature reviews in supply chain management. Supply Chain Manag. 2012, 17, 544-555. [CrossRef]

38. Agrawal, S.; Singh, R.K.; Murtaza, Q. A literature review and perspectives in reverse logistics. Resour. Conserv. Recycl. 2015, 97, 76-92. [CrossRef]

39. Farahani, R.Z.; Rezapour, S.; Drezner, T.; Fallah, S. Competitive supply chain network design: An overview of classifications, models, solution techniques and applications. Omega 2014, 45, 92-118. [CrossRef]

40. Seuring, S.A. Assessing the rigor of case study research in supply chain management. Supply Chain Manag. 2008, 13, 128-137. [CrossRef]

41. Neto, J.Q.F.; Bloemhof-Ruwaard, J.M.; van Nunen, J.A.E.E.; van Heck, E. Designing and evaluating sustainable logistics networks. Int. J. Prod. Econ. 2008, 111, 195-208. [CrossRef]

42. Zhu, Q.; Sarkis, J. Relationships between operational practices and performance among early adopters of green supply chain management practices in Chinese manufacturing enterprises. J. Oper. Manag. 2004, 22, 265-289. [CrossRef]

43. Diabat, A.; Khodaverdi, R.; Olfat, L. An exploration of green supply chain practices and performances in an automotive industry. Int. J. Adv. Manuf. Technol. 2013, 68, 949-961. [CrossRef]

44. Diabat, A.; Govindan, K. An analysis of the drivers affecting the implementation of green supply chain management. Resour. Conserv. Recycl. 2011, 55, 659-667. [CrossRef]

45. Rao, P.; Holt, D. Do green supply chains lead to competitiveness and economic performance? Int. J. Oper. Prod. Manag. 2005, 25, 898-916. [CrossRef]

46. Govindan, K.; Khodaverdi, R.; Vafadarnikjoo, A. Intuitionistic fuzzy based DEMATEL method for developing green practices and performances in a green supply chain. Expert Syst. Appl. 2015, 42, 7207-7220. [CrossRef]

47. Mani, V.; Agrawal, R.; Sharma, V. Supplier selection using social sustainability: AHP based approach in India. Int. Strateg. Manag. Rev. 2014, 2, 98-112. [CrossRef]

48. Guide, V.D.R.; van Wassenhove, L.N. The Evolution of Closed-Loop Supply Chain Research. Oper. Res. 2009, 57, 10-18. [CrossRef]

49. Taticchi, P.; Tonelli, F.; Pasqualino, R. Performance measurement of sustainable supply chains. Int. J. Product. Perform. Manag. 2013, 62, 782-804. [CrossRef]

50. Chaabane, A.; Ramudhin, A.; Paquet, M. Design of sustainable supply chains under the emission trading scheme. Int. J. Prod. Econ. 2012, 135, 37-49. [CrossRef]

51. Abdallah, T.; Diabat, A.; Simchi-Levi, D. Sustainable supply chain design: A closed-loop formulation and sensitivity analysis. Prod. Plan. Control Manag. Oper. 2012, 23, 120-133. [CrossRef]

52. Pop, P.C.; Pintea, C.-M.; Sitar, C.P.; Hajdu-Măcelaru, M. An efficient Reverse Distribution System for solving sustainable supply chain network design problem. J. Appl. Log. 2015, 13, 105-113. [CrossRef]

53. Rostamzadeh, R.; Govindan, K.; Esmaeili, A.; Sabaghi, M. Application of fuzzy VIKOR for evaluation of green supply chain management practices. Ecol. Indic. 2015, 49, 188-203. [CrossRef]

54. Zhu, Q.; Sarkis, J. An inter-sectoral comparison of green supply chain management in China: Drivers and practices. J. Clean. Prod. 2006, 14, 472-486. [CrossRef]

55. Fleischmann, M.; Bloemhof-Ruwaard, J.M.; Dekker, R.; van der Laan, E.; van Nunen, J.A.E.E.; van Wassenhove, L.N. Quantitative models for reverse logistics: A review. Eur. J. Oper. Res. 1997, 103, 1-17. [CrossRef]

56. Marchet, G.; Melacini, M.; Perotti, S. Environmental sustainability in logistics and freight transportation. J. Manuf. Technol. Manag. 2014, 25, 775. [CrossRef]

57. Kongar, E.; Haznedaroglu, E.; Abdelghany, O.; Bahtiyar, M.O. A novel IT infrastructure for reverse logistics operations of end-of-life pharmaceutical products. Inform. Technol. Manag. 2015, 16, 51-65. [CrossRef]

58. Pishvaee, M.S.; Torabi, S.A.; Razmi, J. Credibility-based fuzzy mathematical programming model for green logistics design under uncertainty. Comput. Ind. Eng. 2012, 62, 624-632. [CrossRef]

59. Sundarakani, B.; de Souza, R.; Goh, M.; Wagner, S.M.; Manikandan, S. Modeling carbon footprints across the supply chain. Int. J. Prod. Econ. 2010, 128, 43-50. [CrossRef]

60. Foran, B.; Lenzen, M.; Dey, C.; Bilek, M. Integrating sustainable chain management with triple bottom line accounting. Ecol. Econ. 2005, 52, 143-157. [CrossRef]

61. Ferretti, I.; Zanoni, S.; Zavanella, L.; Diana, A. Greening the aluminium supply chain. Int. J. Prod. Econ. 2007, 108, 236-245. [CrossRef] 
62. Igarashi, K.; Yamada, T.; Gupta, S.M.; Inoue, M.; Itsubo, N. Disassembly system modeling and design with parts selection for cost, recycling and $\mathrm{CO}_{2}$ saving rates using multi criteria optimization. J. Manuf. Syst. 2016, 38, 151-164. [CrossRef]

63. Coley, D.; Howard, M.; Winter, M. Local food, food miles and carbon emissions: A comparison of farm shop and mass distribution approaches. Food Policy 2009, 34, 150-155. [CrossRef]

64. Bloemhof-Ruwaard, J.M.; van Beek, P.; Hordijk, L.; van Wassenhove, L.N. Interactions between operational research and environmental management. Eur. J. Oper. Res. 1995, 85, 229-243. [CrossRef]

65. Hsu, C.-W.; Hu, A.H. Applying hazardous substance management to supplier selection using analytic network process. J. Clean. Prod. 2009, 17, 255-264. [CrossRef]

66. Santibanez-Gonzalez, E.D.R.; Diabat, A. Solving a reverse supply chain design problem by improved Benders decomposition schemes. Comput. Ind. Eng. 2013, 66, 889-898. [CrossRef]

67. Ramos, T.R.P.; Gomes, M.I.; Barbosa-Póvoa, A.P. Planning a sustainable reverse logistics system: Balancing costs with environmental and social concerns. Omega 2014, 48, 60-74. [CrossRef]

68. Capocelli, R.M.; de Luca, A. Fuzzy sets and decision theory. Inform. Control 1973, 23, 446-473. [CrossRef]

69. Lee, D.-H.; Dong, M.; Bian, W. The design of sustainable logistics network under uncertainty. Int. J. Prod. Econ. 2010, 128, 159-166. [CrossRef]

70. Schultmann, F.; Zumkeller, M.; Rentz, O. Modeling reverse logistic tasks within closed-loop supply chains: An example from the automotive industry. Eur. J. Oper. Res. 2006, 171, 1033-1050. [CrossRef]

71. Ko, H.J.; Evans, G.W. A genetic algorithm-based heuristic for the dynamic integrated forward/reverse logistics network for 3PLs. Comput. Oper. Res. 2007, 34, 346-366. [CrossRef]

72. Kannegiesser, M.; Günther, H.O.; Autenrieb, N. The time-to-sustainability optimization strategy for sustainable supply network design. J. Clean. Prod. 2015, 108, 451-463. [CrossRef]

73. Martí, J.M.C.; Tancrez, J.-S.; Seifert, R.W. Carbon footprint and responsiveness trade-offs in supply chain network design. Int. J. Prod. Econ. 2015, 166, 129-142. [CrossRef]

74. Coskun, S.; Ozgur, L.; Polat, O.; Gungor, A. A model proposal for green supply chain network design based on consumer segmentation. J. Clean. Prod. 2016, 110, 149-157. [CrossRef]

75. Vahdani, B.; Tavakkoli-Moghaddam, R.; Modarres, M.; Baboli, A. Reliable design of a forward/reverse logistics network under uncertainty: A robust-M/M/c queuing model. Transp. Res. Part E Logist. Transp. Rev. 2012, 48, 1152-1168. [CrossRef]

76. Orji, I.J.; Wei, S. An innovative integration of fuzzy-logic and systems dynamics in sustainable supplier selection: A case on manufacturing industry. Comput. Ind. Eng. 2015, 88, 1-12. [CrossRef]

77. Georgiadis, P.; Besiou, M. Sustainability in electrical and electronic equipment closed-loop supply chains: A System Dynamics approach. J. Clean. Prod. 2008, 16, 1665-1678. [CrossRef]

78. Tian, Y.; Govindan, K.; Zhu, Q. A system dynamics model based on evolutionary game theory for green supply chain management diffusion among Chinese manufacturers. J. Clean. Prod. 2014, 80, 96-105. [CrossRef]

79. Awudu, I.; Zhang, J. Uncertainties and sustainability concepts in biofuel supply chain management: A review. Renew. Sustain. Energy Rev. 2012, 16, 1359-1368. [CrossRef]

80. Van der Vorst, J.G.A.J.; Tromp, S.-O.; van der Zee, D.-J. Simulation modelling for food supply chain redesign; integrated decision making on product quality, sustainability and logistics. Int. J. Prod. Res. 2009, 47, 6611-6631. [CrossRef]

81. Hu, T.-L.; Sheu, J.-B.; Huang, K.-H. A reverse logistics cost minimization model for the treatment of hazardous wastes. Transp. Res. Part E Logist. Transp. Rev. 2002, 38, 457-473. [CrossRef]

82. Moghaddam, K.S. Fuzzy multi-objective model for supplier selection and order allocation in reverse logistics systems under supply and demand uncertainty. Expert Syst. Appl. 2015, 42, 6237-6254. [CrossRef]

83. Brandenburg, M. A hybrid approach to configure eco-efficient supply chains under consideration of performance and risk aspects. Omega 2017, 70, 58-76. [CrossRef]

84. Sari, K. A novel multi-criteria decision framework for evaluating green supply chain management practices. Comput. Ind. Eng. 2017, 105, 338-347. [CrossRef]

85. Amindoust, A.; Ahmed, S.; Saghafinia, A.; Bahreininejad, A. Sustainable supplier selection: A ranking model based on fuzzy inference system. Appl. Soft Comput. 2012, 12, 1668-1677. [CrossRef] 
86. Humphreys, P.; McCloskey, A.; McIvor, R.; Maguire, L.; Glackin, C. Employing dynamic fuzzy membership functions to assess environmental performance in the supplier selection process. Int. J. Prod. Res. 2006, 44, 2379-2419. [CrossRef]

87. Ghadimi, P.; Heavey, C. 21st CIRP Conference on Life Cycle Engineering. Sustainable Supplier Selection in Medical Device Industry: Toward Sustainable Manufacturing. Procedia CIRP 2014, 15, 165-170. [CrossRef]

88. Büyüközkan, G.; Çifçi, G. A novel fuzzy multi-criteria decision framework for sustainable supplier selection with incomplete information. Comput. Ind. 2011, 62, 164-174. [CrossRef]

89. Shaw, K.; Shankar, R.; Yadav, S.S.; Thakur, L.S. Supplier selection using fuzzy AHP and fuzzy multi-objective linear programming for developing low carbon supply chain. Expert Syst. Appl. 2012, 39, 8182-8192. [CrossRef]

90. Büyüközkan, G.; Çifçi, G. A novel hybrid MCDM approach based on fuzzy DEMATEL, fuzzy ANP and fuzzy TOPSIS to evaluate green suppliers. Expert Syst. Appl. 2012, 39, 3000-3011. [CrossRef]

91. Lee, A.H.I.; Kang, H.-Y.; Hsu, C.-F.; Hung, H.-C. A green supplier selection model for high-tech industry. Expert Syst. Appl. 2009, 36, 7917-7927. [CrossRef]

92. Awasthi, A.; Chauhan, S.S.; Goyal, S.K. A fuzzy multicriteria approach for evaluating environmental performance of suppliers. Int. J. Prod. Econ. 2010, 126, 370-378. [CrossRef]

93. Lu, L.Y.Y.; Wu, C.H.; Kuo, T.-C. Environmental principles applicable to green supplier evaluation by using multi-objective decision analysis. Int. J. Prod. Res. 2007, 45, 4317-4331. [CrossRef]

94. Bali, O.; Kose, E.; Gumus, S. Green supplier selection based on IFS and GRA. Grey Syst. Theory Appl. 2013, 3, 158-176. [CrossRef]

95. Zadeh, L.A. Fuzzy sets. Inform. Control 1965, 8, 338-353. [CrossRef]

96. Olugu, E.U.; Wong, K.Y. An expert fuzzy rule-based system for closed-loop supply chain performance assessment in the automotive industry. Expert Syst. Appl. 2012, 39, 375-384. [CrossRef]

97. Erol, I.; Sencer, S.; Sari, R. A new fuzzy multi-criteria framework for measuring sustainability performance of a supply chain. Ecol. Econ. 2011, 70, 1088-1100. [CrossRef]

98. Akman, G. Evaluating suppliers to include green supplier development programs via fuzzy c-means and VIKOR methods. Comput. Ind. Eng. 2015, 86, 69-82. [CrossRef]

99. Shan, L. Research on Green Logistics Service Providers Selection Based on Intuitionistic Language Fuzzy Entropy. J. Comput. 2012, 7, 540-546. [CrossRef]

100. Lee, J.-E.; Chung, K.-Y.; Lee, K.-D.; Gen, M. A multi-objective hybrid genetic algorithm to minimize the total cost and delivery tardiness in a reverse logistics. Multimed. Tools Appl. 2015, 74, 9067-9085. [CrossRef]

101. Govindan, K.; Murugesan, P. Selection of third-party reverse logistics provider using fuzzy extent analysis. Benchmarking 2011, 18, 149-167. [CrossRef]

102. Kannan, D.; Govindan, K.; Rajendran, S. Fuzzy Axiomatic Design approach based green supplier selection: Acase study from Singapore. J. Clean. Prod. 2015, 96, 194-208. [CrossRef]

103. Pishvaee, M.S.; Razmi, J.; Torabi, S.A. Robust possibilistic programming for socially responsible supply chain network design: A new approach. Fuzzy Sets Syst. 2012, 206, 1-20. [CrossRef]

104. Kannan, D.; Khodaverdi, R.; Olfat, L.; Jafarian, A.; Diabat, A. Integrated fuzzy multi criteria decision making method and multi-objective programming approach for supplier selection and order allocation in a green supply chain. J. Clean. Prod. 2013, 47, 355-367. [CrossRef]

105. Subulan, K.; Taşan, A.S.; Baykasoğlu, A. Designing an environmentally conscious tire closed-loop supply chain network with multiple recovery options using interactive fuzzy goal programming. Appl. Math. Model. 2015, 39, 2661-2702. [CrossRef]

106. Vahdani, B.; Tavakkoli-Moghaddam, R.; Jolai, F. Reliable design of a logistics network under uncertainty: A fuzzy possibilistic-queuing model. Appl. Math. Model. 2013, 37, 3254-3268. [CrossRef]

107. Amin, S.H.; Zhang, G. An integrated model for closed-loop supply chain configuration and supplier selection: Multi-objective approach. Expert Syst. Appl. 2012, 39, 6782-6791. [CrossRef]

108. Saaty, T.L. The Analytic Hierarchy Process; McGraw-Hill International: New York, NY, USA, 1980.

109. Saaty, T.L. The Analytic Network Process (ANP); RWS Publications: Pittsburgh, PA, USA, 1996.

110. Pochampally, K.K.; Nukala, S.; Gupta, S.M. Strategic Planning Models for Reverse and Closed-Loop Supply Chains; CRC Press: Boca Raton, FL, USA, 2008.

111. Tuzkaya, G.; Ozgen, A.; Ozgen, D.; Tuzkaya, U.R. Environmental performance evaluation of suppliers: A hybrid fuzzy multi-criteria decision approach. Int. J. Environ. Sci. Technol. 2009, 6, 477-490. [CrossRef] 
112. Wang, X.; Chan, H.K.; Yee, R.W.Y.; Diaz-Rainey, I. A two-stage fuzzy-AHP model for risk assessment of implementing green initiatives in the fashion supply chain. Int. J. Prod. Econ. 2012, 135, 595-606. [CrossRef]

113. Wu, W.-W. Choosing knowledge management strategies by using a combined ANP and DEMATEL approach. Expert Syst. Appl. 2008, 35, 828-835. [CrossRef]

114. Efendigil, T.; Önüt, S.; Kongar, E. A holistic approach for selecting a third-party reverse logistics provider in the presence of vagueness. Comput. Ind. Eng. 2008, 54, 269-287. [CrossRef]

115. Shakourloo, A.; Kazemi, A.; Javad, M.O.M. A new model for more effective supplier selection and remanufacturing process in a closed-loop supply chain. Appl. Math. Model. 2016, 40, 9914-9931. [CrossRef]

116. Hwang, C.-L.; Yoon, K. Multiple Attribute Decision Making: Methods and Applications; Springer: Berlin, Germany, 1981.

117. Kannan, G.; Pokharel, S.; Kumar, P.S. A hybrid approach using ISM and fuzzy TOPSIS for the selection of reverse logistics provider. Resour. Conserv. Recycl. 2009, 54, 28-36. [CrossRef]

118. Fallahpour, A.; Olugu, E.U.; Musa, S.N.; Wong, K.Y.; Noori, S. A decision support model for sustainable supplier selection in sustainable supply chain management. Comput. Ind. Eng. 2017, 105, 391-410. [CrossRef]

119. Prakash, C.; Barua, M.K. An analysis of integrated robust hybrid model for third-party reverse logistics partner selection under fuzzy environment. Resour. Conserv. Recycl. 2016, 108, 63-81. [CrossRef]

120. Govindan, K.; Khodaverdi, R.; Jafarian, A. A fuzzy multi criteria approach for measuring sustainability performance of a supplier based on triple bottom line approach. J. Clean. Prod. 2013, 47, 345-354. [CrossRef]

121. Gabus, A.; Fontela, E. World Problems, an Invitation to Further Thought within the Framework of DEMATEL; Battelle Geneva Research Center: Geneva, Switzerland, 1972.

122. Gabus, A.; Fontela, E. Perceptions of the World Problematique: Communication Procedure, Communicating with Those Bearing Collective Responsibility; Battelle Geneva Research Centre: Geneva, Switzerland, 1973.

123. Lin, R.-J. Using fuzzy DEMATEL to evaluate the green supply chain management practices. J. Clean. Prod. 2013, 40, 32-39. [CrossRef]

124. Wu, K.-J.; Liao, C.-J.; Tseng, M.-L.; Chiu, A.S.F. Exploring decisive factors in green supply chain practices under uncertainty. Int. J. Prod. Econ. 2015, 159, 147-157. [CrossRef]

125. Lin, R.-J.; Chen, R.-H.; Nguyen, T.-H. Green supply chain management performance in automobile manufacturing industry under uncertainty. Procedia Soc. Behav. Sci. 2011, 25, 233-245. [CrossRef]

126. Wu, K.-J.; Liao, C.-J.; Tseng, M.-L.; Lim, M.K.; Hu, J.; Tan, K. Toward sustainability: Using big data to explore the decisive attributes of supply chain risks and uncertainties. J. Clean. Prod. 2017, 142, 663-676. [CrossRef]

127. Opricovic, S. Multicriteria optimization of civil engineering systems. Fac. Civ. Eng. Belgrad. 1998, 2, 5-21.

128. Büyüközkan, G.; Feyzioğlu, O. Evaluation of Suppliers' Environmental Management Performances by a Fuzzy Compromise Ranking Technique. J. Mult. Valued Log. Soft Comput. 2008, 14, 309-324.

129. Banaeian, N.; Mobli, H.; Fahimnia, B.; Nielsen, I.E.; Omid, M. Green supplier selection using fuzzy group decision making methods: A case study from the agri-food industry. Comput. Oper. Res. 2016. [CrossRef]

130. Prakash, C.; Barua, M.K. A combined MCDM approach for evaluation and selection of third-party reverse logistics partner for Indian electronics industry. Sustain. Prod. Consum. 2016, 7, 66-78. [CrossRef]

131. Awasthi, A.; Kannan, G. Green supplier development program selection using NGT and VIKOR under fuzzy environment. Comput. Ind. Eng. 2016, 91, 100-108. [CrossRef]

132. Kuo, R.J.; Wang, Y.C.; Tien, F.C. Integration of artificial neural network and MADA methods for green supplier selection. J. Clean. Prod. 2010, 18, 1161-1170. [CrossRef]

133. Mirhedayatian, S.M.; Azadi, M.; Saen, R.F. A novel network data envelopment analysis model for evaluating green supply chain management. Int. J. Prod. Econ. 2014, 147, 544-554. [CrossRef]

134. Azadi, M.; Jafarian, M.; Saen, R.F.; Mirhedayatian, S.M. A new fuzzy DEA model for evaluation of efficiency and effectiveness of suppliers in sustainable supply chain management context. Comput. Oper. Res. 2015, 54, 274-285. [CrossRef]

135. Fallahpour, A.; Olugu, E.U.; Musa, S.N.; Khezrimotlagh, D.; Wong, K.Y. An integrated model for green supplier selection under fuzzy environment: Application of data envelopment analysis and genetic programming approach. Neural Comput. Appl. 2016, 27, 707-725. [CrossRef]

136. Zhou, X.; Pedrycz, W.; Kuang, Y.; Zhang, Z. Type-2 fuzzy multi-objective DEA model: An application to sustainable supplier evaluation. Appl. Soft Comput. 2016, 46, 424-440. [CrossRef]

137. Brans, J.-P.; Vincke, P.; Mareschal, B. How to select and how to rank projects: The PROMETHEE method. Eur. J. Oper. Res. 1986, 24, 228-238. [CrossRef] 
138. Tuzkaya, U.R. Evaluating the environmental effects of transportation modes using an integrated methodology and an application. Int. J. Environ. Sci. Technol. 2009, 6, 277-290. [CrossRef]

139. E Costa, C.A.B.; Vansnick, J.-C. MACBETH-An interactive path towards the construction of cardinal value functions. Int. Trans. Oper. Res. 1994, 1, 489-500. [CrossRef]

140. Dhouib, D. An extension of MACBETH method for a fuzzy environment to analyze alternatives in reverse logistics for automobile tire wastes. Omega 2014, 42, 25-32. [CrossRef]

141. Deng, J.-L. Control problems of grey systems. Syst. Control Lett. 1982, 1, 288-294.

142. Tseng, M.-L. Green supply chain management with linguistic preferences and incomplete information. Appl. Soft Comput. 2011, 11, 4894-4903. [CrossRef]

143. Tseng, M.-L.; Chiu, A.S.F. Evaluating firm's green supply chain management in linguistic preferences. J. Clean. Prod. 2013, 40, 22-31. [CrossRef]

144. Wu, K.-J.; Liao, C.-J.; Tseng, M.; Chiu, K.K.-S. Multi-attribute approach to sustainable supply chain management under uncertainty. Ind. Manag. Data Syst. 2016, 116, 777-800. [CrossRef]

145. Pawlak, Z. Rough sets. Int. J. Comput. Inform. Sci. 1982, 11, 341-356. [CrossRef]

146. Kusi-Sarpong, S.; Bai, C.; Sarkis, J.; Wang, X. Green supply chain practices evaluation in the mining industry using a joint rough sets and fuzzy TOPSIS methodology. Resourc. Policy 2015, 46, 86-100. [CrossRef]

147. Bai, C.; Dhavale, D.; Sarkis, J. Complex investment decisions using rough set and fuzzy c-means: An example of investment in green supply chains. Eur. J. Oper. Res. 2016, 248, 507-521. [CrossRef]

148. Myerson, R.B. Game Theory: Analysis of Conflict; Harvard University: Cambridge, MA, USA, 1991.

149. Neumann, J.V.; Morgenstern, O. Theory of Games and Economic Behavior; Princeton University Press: Princeton, NJ, USA, 1944; Volume 60.

150. Zhao, R.; Neighbour, G.; Han, J.; McGuire, M.; Deutz, P. Using game theory to describe strategy selection for environmental risk and carbon emissions reduction in the green supply chain. J. Loss Prev. Process Ind. 2012, 25, 927-936. [CrossRef]

151. Wei, J.; Zhao, J. Pricing decisions with retail competition in a fuzzy closed-loop supply chain. Expert Syst. Appl. 2011, 38, 11209-11216. [CrossRef]

152. Wei, J.; Zhao, J. Reverse channel decisions for a fuzzy closed-loop supply chain. Appl. Math. Model. 2013, 37, 1502-1513. [CrossRef]

153. Yang, D.; Xiao, T. Pricing and green level decisions of a green supply chain with governmental interventions under fuzzy uncertainties. J. Clean. Prod. 2017, 149, 1174-1187. [CrossRef]

154. Jakhar, S.K. Performance evaluation and a flow allocation decision model for asustainable supply chain of an apparel industry. J. Clean. Prod. 2015, 87, 391-413. [CrossRef]

155. Azadnia, A.H.; Saman, M.Z.M.; Wong, K.Y.; Ghadimi, P.; Zakuan, N. Sustainable Supplier Selection based on Self-organizing Map Neural Network and Multi Criteria Decision Making Approaches. Procedia Soc. Behav. Sci. 2012, 65, 879-884. [CrossRef]

156. Gold, S.; Awasthi, A. Sustainable global supplier selection extended towards sustainability risks from $(1+n)$ th tier suppliers using fuzzy AHP based approach. IFAC PapersOnLine 2015, 48, 966-971. [CrossRef]

157. Öztürk, B.A.; Özçelik, F. Sustainable Supplier Selection with A Fuzzy Multi-Criteria Decision Making Method Based on Triple Bottom Line. Bus. Econ. Res. J. 2014, 5, 129-147.

158. Balaman, S..Y.; Selim, H. A fuzzy multiobjective linear programming model for design and management of anaerobic digestion based bioenergy supply chains. Energy 2014, 74, 928-940. [CrossRef]

159. Dotoli, M.; Epicoco, N.; Falagario, M. A Technique for Supply Chain Network Design under Uncertainty using Cross-Efficiency Fuzzy Data Envelopment Analysis. IFAC PapersOnLine 2015, 48, 634-639. [CrossRef]

160. Balaman, Ş.Y.; Selim, H. Sustainable design of renewable energy supply chains integrated with district heating systems: A fuzzy optimization approach. J. Clean. Prod. 2016, 133, 863-885. [CrossRef]

161. Firoozi, M.; Siadat, A.; Salehi, N.; Mousavi, S.M. A novel multi-objective fuzzy mathematical model for designing a sustainable supply chain network considering outsourcing risk under uncertainty. In Proceedings of the 2013 IEEE International Conference on Industrial Engineering and Engineering Management, Bangkok, Thailand, 10-13 December 2013; pp. 88-92.

162. Babazadeh, R.; Razmi, J.; Pishvaee, M.S.; Rabbani, M. A sustainable second-generation biodiesel supply chain network design problem under risk. Omega 2017, 66, 258-277. [CrossRef]

163. Uysal, F. An Integrated Model for Sustainable Performance Measurement in Supply Chain. Procedia Soc. Behav. Sci. 2012, 62, 689-694. [CrossRef] 
164. Zhalechian, M.; Tavakkoli-Moghaddam, R.; Zahiri, B.; Mohammadi, M. Sustainable design of a closed-loop location-routing-inventory supply chain network under mixed uncertainty. Transp. Res. Part E Logist. Transp. Rev. 2016, 89, 182-214. [CrossRef]

165. Büyüközkan, G.; Çifçi, G. An integrated QFD framework with multiple formatted and incomplete preferences: A sustainable supply chain application. Appl. Soft Comput. 2013, 13, 3931-3941. [CrossRef]

166. Mangla, S.K.; Kumar, P.; Barua, M.K. Prioritizing the responses to manage risks in green supply chain: An Indian plastic manufacturer perspective. Sustain. Prod. Consum. 2015, 1, 67-86. [CrossRef]

167. Ren, J.; Manzardo, A.; Toniolo, S.; Scipioni, A. Sustainability of hydrogen supply chain. Part II: Prioritizing and classifying the sustainability of hydrogen supply chains based on the combination of extension theory and AHP. Int. J. Hydrog. Energy 2013, 38, 13845-13855. [CrossRef]

168. Mangla, S.K.; Govindan, K.; Luthra, S. Prioritizing the barriers to achieve sustainable consumption and production trends in supply chains using fuzzy Analytical Hierarchy Process. J. Clean. Prod. 2017, 151, 509-525. [CrossRef]

169. Kumar, D.; Rahman, Z.; Chan, F.T.S. A fuzzy AHP and fuzzy multi-objective linear programming model for order allocation in a sustainable supply chain: A case study. Int. J. Comput. Integr. Manuf. 2017, 30, 535-551. [CrossRef]

170. Rodger, J.A.; George, J.A. Triple bottom line accounting for optimizing natural gas sustainability: A statistical linear programming fuzzy ILOWA optimized sustainment model approach to reducing supply chain global cybersecurity vulnerability through information and communications technology. J. Clean. Prod. 2017, 142, 1931-1949.

171. Sahu, N.K.; Datta, S.; Mahapatra, S.S. Green supplier appraisement in fuzzy environment. Benchmarking 2014, 21, 412-429. [CrossRef]

172. Ghorabaee, M.K.; Zavadskas, E.K.; Amiri, M.; Esmaeili, A. Multi-criteria evaluation of green suppliers using an extended WASPAS method with interval type-2 fuzzy sets. J. Clean. Prod. 2016, 137, 213-229. [CrossRef]

173. Yazdani, M. An integrated MCDM approach to green supplier selection. Int. J. Ind. Engi. Comput. 2014, 5, 443-458. [CrossRef]

174. Lakhal, S.Y.; H’Mida, S.; Islam, M.R. Green supply chain parameters for a Canadian petroleum refinery company. Int.J. Environ. Technol. Manag. 2007, 7, 56-67. [CrossRef]

175. Huang, S.-Y.; Wang, C.-Y.; Chiou, C.-Y. FAHP Application for Green Supplier Selection in Electronic Industry. J. Hum. Resour. Adult Learn. 2014, 10, 49-60.

176. Tzong-Ru, L.; Nha, L.T.P.; Genovese, A.; Lenny, S.C.K. Using FAHP to determine the criteria for partner's selection within a green supply chain. J. Manuf. Technol. Manag. 2012, 23, 25-55.

177. Grisi, R.M.; Guerra, L.; Naviglio, G. Supplier performance evaluation for green supply chain management. In Business Performance Measurement and Management; Springer: Berlin, Germany, 2010; pp. 149-163.

178. Bakeshlou, E.A.; Khamseh, A.A.; Asl, M.A.G.; Sadeghi, J.; Abbaszadeh, M. Evaluating a green supplier selection problem using a hybrid MODM algorithm. J. Intell. Manuf. 2014, 1-15. [CrossRef]

179. Hsu, C.W.; Chen, S.H.; Chiou, C.Y. A model for carbon management of supplier selection in green supply chain management. In Proceedings of the 2011 IEEE International Conference on Industrial Engineering and Engineering Management (IEEM), Singapore, 6-9 December 2011; pp. 1247-1250.

180. Shen, L.; Olfat, L.; Govindan, K.; Khodaverdi, R.; Diabat, A. A fuzzy multi criteria approach for evaluating green supplier's performance in green supply chain with linguistic preferences. Resour. Conserv. Recycl. 2013, 74, 170-179. [CrossRef]

181. Govindan, K.; Sivakumar, R. Green supplier selection and order allocation in a low-carbon paper industry: Integrated multi-criteria heterogeneous decision-making and multi-objective linear programming approaches. Ann. Oper. Res. 2016, 238, 243-276. [CrossRef]

182. Mavi, R.K.; Goh, M.; Mavi, N.K. Supplier Selection with Shannon Entropy and Fuzzy TOPSIS in the Context of Supply Chain Risk Management. Procedia Soc. Behav. Sci. 2016, 235, 216-225. [CrossRef]

183. Tsai, W.H.; Hung, S.-J. A fuzzy goal programming approach for green supply chain optimisation under activity-based costing and performance evaluation with a value-chain structure. Int. J. Prod. Res. 2009, 47, 4991-5017. [CrossRef]

184. Baoqin, Y.; Cui, S.; Xu, Z. The green supply chain management based on EMS. In Proceedings of the 2008 IEEE International Conference on Automation and Logistics, Qingdao, China, 1-3 September 2008; pp. 2199-2204. 
185. Mangla, S.K.; Kumar, P.; Barua, M.K. Risk analysis in green supply chain using fuzzy AHP approach: A case study. Resour. Conserv. Recycl. 2015, 104, 375-390. [CrossRef]

186. Boutkhoum, O.; Hanine, M.; Tikniouine, A.; Agouti, T. Multi-criteria Decisional Approach of the OLAP Analysis by Fuzzy Logic: Green Logistics as a Case Study. Arab. J. Sci. Eng. 2015, 40, 2345-2359. [CrossRef]

187. Hsu, C.W.; Hu, A.H. Green supply chain management in the electronic industry. Int. J. Environ. Sci. Technol. 2008, 5, 205-216. [CrossRef]

188. Mangla, S.K.; Kumar, P.; Barua, M.K. An integrated methodology of FTA and fuzzy AHP for risk assessment in green supply chain. Int. J. Oper. Res. 2016, 25, 77-99. [CrossRef]

189. Thamsatitdej, P.; Jongpaiboon, M.; Samaranayake, P.; Laosirihongthong, T. Green supply chain management, triple bottom line, and organizational theory-Prioritization with fuzzy AHP method. In Proceedings of the 2015 IEEE International Conference on Industrial Engineering and Engineering Management (IEEM), Singapore, 6-9 December 2015; pp. 1588-1592.

190. Wu, K.-J.; Tseng, M.-L.; Vy, T. Evaluation the drivers of green supply chain management practices in uncertainty. Procedia Soc. Behav. Sci. 2011, 25, 384-397. [CrossRef]

191. Kusi-Sarpong, S.; Sarkis, J.; Wang, X. Assessing green supply chain practices in the Ghanaian mining industry: A framework and evaluation. Int. J. Prod. Econ. 2016, 181, 325-341. [CrossRef]

192. Wang, Z.; Mathiyazhagan, K.; Xu, L.; Diabat, A. A decision making trial and evaluation laboratory approach to analyze the barriers to Green Supply Chain Management adoption in a food packaging company. J. Clean. Prod. 2016, 117, 19-28. [CrossRef]

193. Wang, X.; Chan, H.K. A hierarchical fuzzy TOPSIS approach to assess improvement areas when implementing green supply chain initiatives. Int. J. Prod. Res. 2013, 51, 3117-3130. [CrossRef]

194. Wang, H.-F.; Hsu, H.-W. Resolution of an uncertain closed-loop logistics model: An application to fuzzy linear programs with risk analysis. J. Environ. Manag. 2010, 91, 2148-2162. [CrossRef] [PubMed]

195. Balaman, Ş.Y.; Selim, H. A decision model for cost effective design of biomass based green energy supply chains. Bioresour. Technol. 2015, 191, 97-109. [CrossRef] [PubMed]

196. Chen, C.C.; Tseng, M.L.; Lin, Y.H.; Lin, Z.S. Implementation of green supply chain management in uncertainty. In Proceedings of the 2010 IEEE International Conference on Industrial Engineering and Engineering Management (IEEM), Macao, China, 7-10 December 2010; pp. 260-264.

197. Mohammed, A.; Wang, Q. The fuzzy multi-objective distribution planner for a green meat supply chain. Int. J. Prod. Econ. 2017, 184, 47-58. [CrossRef]

198. Tseng, M.-L.; Lim, M.; Wu, K.-J.; Zhou, L.; Bui, D.T.D. A novel approach for enhancing green supply chain management using converged interval-valued triangular fuzzy numbers-grey relation analysis. Resour. Conserv. Recycl. 2017. [CrossRef]

199. Mangla, S.K.; Kumar, P.; Barua, M.K. Flexible Decision Modeling for Evaluating the Risks in Green Supply Chain Using Fuzzy AHP and IRP Methodologies. Glob. J. Flex. Syst. Manag. 2015, 16, 19-35. [CrossRef]

200. Sofyalıoğlu, Ç.; Kartal, B. The Selection of Global Supply Chain Risk Management Strategies by Using Fuzzy Analytical Hierarchy Process-A Case from Turkey. Procedia Soc. Behav. Sci. 2012, 58, 1448-1457. [CrossRef]

201. Zimmer, K.; Fröhling, M.; Breun, P.; Schultmann, F. Assessing social risks of global supply chains: A quantitative analytical approach and its application to supplier selection in the German automotive industry. J. Clean. Prod. 2017, 149, 96-109. [CrossRef]

202. Bhattacharya, A.; Mohapatra, P.; Kumar, V.; Dey, P.K.; Brady, M.; Tiwari, M.K.; Nudurupati, S.S. Green supply chain performance measurement using fuzzy ANP-based balanced scorecard: A collaborative decision-making approach. Prod. Plan. Control 2014, 25, 698-714. [CrossRef]

203. Zhang, X.; Zhao, Z. Study of Green Supply Chain and its Performance Based on Fuzzy AHP and Measurement System. In Proceedings of the 2009 International Conference on E-Business and Information System Security, Wuhan, China, 23-24 May 2009; pp. 1-5.

204. Rostamy, A.A.A.; Shaverdi, M.; Ramezani, I. Green supply chain management evaluation in publishing industry based on fuzzy AHP approach. J. Logist. Manag. 2013, 2, 9-14.

205. Pishvaee, M.S.; Razmi, J. Environmental supply chain network design using multi-objective fuzzy mathematical programming. Appl. Math. Model. 2012, 36, 3433-3446. [CrossRef]

206. Pinto-Varela, T.; Barbosa-Póvoa, A.P.F.D.; Novais, A.Q. Bi-objective optimization approach to the design and planning of supply chains: Economic versus environmental performances. Comput. Chem. Eng. 2011, 35, 1454-1468. [CrossRef] 
207. Mousazadeh, M.; Torabi, S.A.; Pishvaee, M.S. Green and Reverse Logistics Management Under Fuzziness. In Supply Chain Management Under Fuzziness: Recent Developments and Techniques; Kahraman, C., Öztayşi, B., Eds.; Springer: Berlin, Germany, 2014; pp. 607-637.

208. Ćirović, G.; Pamučar, D.; Božanić, D. Green logistic vehicle routing problem: Routing light delivery vehicles in urban areas using a neuro-fuzzy model. Expert Syst. Appl. 2014, 41, 4245-4258. [CrossRef]

209. Tseng, M.-L.; Lin, R.-J.; Lin, Y.-H.; Chen, R.-H.; Tan, K. Close-loop or open hierarchical structures in green supply chain management under uncertainty. Expert Syst. Appl. 2014, 41, 3250-3260. [CrossRef]

210. Uygun, Ö.; Dede, A. Performance evaluation of green supply chain management using integrated fuzzy multi-criteria decision making techniques. Comput. Ind. Eng. 2016, 102, 502-511. [CrossRef]

211. Chiu, M.-C.; Teng, L.-W. Sustainable product and supply chain design decisions under uncertainties. Int. J. Precis. Eng. Manuf. 2013, 14, 1953-1960. [CrossRef]

212. Tuzkaya, G.; Gülsün, B. Evaluating centralized return centers in a reverse logistics network: An integrated fuzzy multi-criteria decision approach. Int. J. Environ. Sci. Technol. 2008, 5, 339-352. [CrossRef]

213. Qin, Z.; Ji, X. Logistics network design for product recovery in fuzzy environment. Eur. J. Oper. Res. 2010, 202, 479-490. [CrossRef]

214. Subulan, K.; Baykasoğlu, A.; Özsoydan, F.B.; Taşan, A.S.; Selim, H. A case-oriented approach to a lead/acid battery closed-loop supply chain network design under risk and uncertainty. J. Manuf. Syst. 2015, 37, 340-361. [CrossRef]

215. Jindal, A.; Sangwan, K.S.; Saxena, S. Network Design and Optimization for Multi-product, Multi-time, Multi-echelon Closed-loop Supply Chain under Uncertainty. Procedia CIRP 2015, 29, 656-661. [CrossRef]

216. Alimoradi, A.; Yussuf, R.M.; Ismail, N.B.; Zulkifli, N. Developing a fuzzy linear programming model for locating recovery facility in a closed loop supply chain. Int. J. Sustain. Eng. 2015, 8, 122-137. [CrossRef]

217. Demirel, N.; Özceylan, E.; Paksoy, T.; Gökçen, H. A genetic algorithm approach for optimising a closed-loop supply chain network with crisp and fuzzy objectives. Int. J. Prod. Res. 2014, 52, 3637-3664. [CrossRef]

218. Ramezani, M.; Kimiagari, A.M.; Karimi, B.; Hejazi, T.H. Closed-loop supply chain network design under a fuzzy environment. Knowl. Based Syst. 2014, 59, 108-120. [CrossRef]

219. Soleimani, H.; Govindan, K.; Saghafi, H.; Jafari, H. Fuzzy multi-objective sustainable and green closed-loop supply chain network design. Comput. Ind. Eng. 2017, 109, 191-203. [CrossRef]

220. Govindan, K.; Paam, P.; Abtahi, A.-R. A fuzzy multi-objective optimization model for sustainable reverse logistics network design. Ecol. Indic. 2016, 67, 753-768. [CrossRef]

221. Mirakhorli, A. Fuzzy multi-objective optimization for closed loop logistics network design in bread-producing industries. Int. J. Adv. Manuf. Technol. 2014, 70, 349-362. [CrossRef]

222. Subulan, K.; Taşan, A.S.; Baykasoğlu, A. A fuzzy goal programming model to strategic planning problem of a lead/acid battery closed-loop supply chain. J. Manuf. Syst. 2015, 37, 243-264. [CrossRef]

223. Mehrbod, M.; Tu, N.; Miao, L.; Wenjing, D. Interactive fuzzy goal programming for a multi-objective closed-loop logistics network. Ann. Oper. Res. 2012, 201, 367-381. [CrossRef]

224. Talaei, M.; Moghaddam, B.F.; Pishvaee, M.S.; Bozorgi-Amiri, A.; Gholamnejad, S. A robust fuzzy optimization model for carbon-efficient closed-loop supply chain network design problem: A numerical illustration in electronics industry. J. Clean. Prod. 2016, 113, 662-673. [CrossRef]

225. Farrokh, M.; Azar, A.; Jandaghi, G.; Ahmadi, E. A novel robust fuzzy stochastic programming for closed loop supply chain network design under hybrid uncertainty. Fuzzy Sets Syst. 2017. [CrossRef]

226. Bouzon, M.; Govindan, K.; Rodriguez, C.M.T.; Campos, L.M.S. Identification and analysis of reverse logistics barriers using fuzzy Delphi method and AHP. Resour. Conserv. Recycl. 2016, 108, 182-197. [CrossRef]

227. Tavana, M.; Zareinejad, M.; di Caprio, D.; Kaviani, M.A. An integrated intuitionistic fuzzy AHP and SWOT method for outsourcing reverse logistics. Appl. Soft Comput. 2016, 40, 544-557. [CrossRef]

228. Malviya, R.K.; Kant, R. Hybrid decision making approach to predict and measure the success possibility of green supply chain management implementation. J. Clean. Prod. 2016, 135, 387-409. [CrossRef]

229. Senthil, S.; Srirangacharyulu, B.; Ramesh, A. A Decision Making Methodology for the Selection of Reverse Logistics Operating Channels. Procedia Eng. 2012, 38, 418-428. [CrossRef]

230. Niknejad, A.; Petrovic, D. Optimisation of integrated reverse logistics networks with different product recovery routes. Eur. J. Oper. Res. 2014, 238, 143-154. [CrossRef]

231. Özceylan, E.; Paksoy, T. Fuzzy multi-objective linear programming approach for optimising a closed-loop supply chain network. Int. J. Prod. Res. 2013, 51, 2443-2461. [CrossRef] 
232. Phuc, P.N.K.; Yu, V.F.; Tsao, Y.-C. Optimizing fuzzy reverse supply chain for end-of-life vehicles. Comput. Ind. Eng. 2016. [CrossRef]

233. Mohajeri, A.; Fallah, M. A carbon footprint-based closed-loop supply chain model under uncertainty with risk analysis: A case study. Transp. Res. Part D Transp. Environ. 2016, 48, 425-450. [CrossRef]

234. Pishvaee, M.S.; Torabi, S.A. A possibilistic programming approach for closed-loop supply chain network design under uncertainty. Fuzzy Sets Syst. 2010, 161, 2668-2683. [CrossRef]

235. Kannan, G.; Murugesan, P.; Senthil, P.; Haq, A.N. Multicriteria group decision making for the third party reverse logistics service provider in the supply chain model using fuzzy TOPSIS for transportation services. Int. J. Serv. Technol. Manag. 2009, 11, 162-181. [CrossRef]

236. Meng, K.; Lou, P.; Peng, X.; Prybutok, V. A hybrid approach for performance evaluation and optimized selection of recoverable end-of-life products in the reverse supply chain. Comput. Ind. Eng. 2016, 98, 171-184. [CrossRef]

237. Nukala, S.; Gupta, S.M. A fuzzy mathematical programming approach for supplier selection in a closed-loop supply chain network. In Proceedings of the 2007 POMS-Dallas Meeting, Dallas, TX, USA, 4-7 May 2007; pp. 4-7.

238. Vahdani, B.; Razmi, J.; Tavakkoli-Moghaddam, R. Fuzzy Possibilistic Modeling for Closed Loop Recycling Collection Networks. Environ. Model. Assess. 2012, 17, 623-637. [CrossRef]

239. Yeh, C.-H.; Xu, Y. Sustainable planning of e-waste recycling activities using fuzzy multicriteria decision making. J. Clean. Prod. 2013, 52, 194-204. [CrossRef]

240. Azadeh, A.; Raoofi, Z.; Zarrin, M. A multi-objective fuzzy linear programming model for optimization of natural gas supply chain through a greenhouse gas reduction approach. J. Nat. Gas Sci. Eng. 2015, 26, 702-710. [CrossRef]

241. Ignatius, J.; Ghasemi, M.R.; Zhang, F.; Emrouznejad, A.; Hatami-Marbini, A. Carbon efficiency evaluation: An analytical framework using fuzzy DEA. Eur. J. Oper. Res. 2016, 253, 428-440. [CrossRef]

242. Aviso, K.B.; Tan, R.R.; Culaba, A.B.; Cruz, J.B., Jr. Fuzzy input-output model for optimizing eco-industrial supply chains under water footprint constraints. J. Clean. Prod. 2011, 19, 187-196. [CrossRef]

(C) 2017 by the authors. Licensee MDPI, Basel, Switzerland. This article is an open access article distributed under the terms and conditions of the Creative Commons Attribution (CC BY) license (http:/ / creativecommons.org/licenses/by/4.0/). 